\title{
Ecosystem services show variable responses to future climate conditions in the Colombian páramos
}

\author{
Mauricio Diazgranados ${ }^{\text {Corresp., }}{ }^{\text {, }}$, Carolina Tovar ${ }^{2}$, Thomas R Etherington ${ }^{2,3}$, Paula Rodríguez-Zorro ${ }^{4}$, Carolina \\ Castellanos-Castro ${ }^{5}$, Manuel Galvis Rueda ${ }^{6}$, Suzette G A Flantua ${ }^{\text {Corresp. 1, } 7,8}$ \\ 1 \\ ${ }^{1}$ Natural Capital and Plant Health Department, Royal Botanic Gardens, Kew, Ardingly, West Sussex, United Kingdom \\ 3 Manaaki Whenua - Landcare Research, Lincoln, New Zealand \\ 4 Institut des Sciences de l'Évolution Montpellier (ISEM), Université de Montpellier, Montpellier, France \\ Ciencias Básicas de la Biodiversidad, Instituto de Investigación de Recursos Biológicos Alexander von Humboldt, Bogotá, Colombia \\ 6 \\ Departamento de Biología, Grupo de Investigación en Estudios Micro y Macro Ambientales (MICRAM), Universidad Tecnológica y Pedagógica de \\ Colombia, Tunja, Colombia \\ 7 \\ Department of Biological Sciences, University of Bergen, Bergen, Norway \\ 8 Institute for Biodiversity \& Ecosystem Dynamics, University of Amsterdam, Amsterdam, Netherlands
}

Corresponding Authors: Mauricio Diazgranados, Suzette G A Flantua

Email address: M.Diazgranados@kew.org, S.G.A.Flantua@gmail.com

Background. The páramos, the high-elevation ecosystems of the northern Andes, are well-known for their high species richness and provide a variety of ecosystem services to local subsistence-based communities and regional urbanizations. Climate change is expected to negatively affect the provision of these services, but the level of this impact is still unclear. Here we assess future climate change impact on the ecosystem services provided by the critically important páramos of the department of Boyacá in Colombia, of which over $25 \%$ of its territory is páramo.

Methods. We first performed an extensive literature review to identify useful species of Boyacá, and selected 103 key plant species that, based on their uses, support the provision of ecosystem services in the páramos. We collated occurrence information for each key species and using a Mahalanobis distance approach we applied climate niche modelling for current and future conditions.

Results. We show an overall tendency of reduction in area for all ecosystem services under future climate conditions (mostly a loss of $10 \%$ but reaching up to a loss of $40 \%$ ), but we observe also increases, and responses differ in intensity loss. Services such as Food for animals, Material and Medicinal, show a high range of changes that includes both positive and negative outcomes, while for Food for humans the responses are mostly substantially negative. Responses are less extreme than those projected for individual species but are often complex because a given ecosystem service is provided by several species. As the level of functional or ecological redundancy between species is not yet known, there is an urgency to expand our knowledge on páramos ecosystem services for more species. Our results are crucial for decision-makers, social and conservation organizations to support sustainable strategies to monitor and mitigate the potential consequences of climate change for human livelihoods in mountainous settings. 


\section{Ecosystem services show variable responses to future climate 2 conditions in the Colombian páramos}

3

4 Mauricio Diazgranados ${ }^{1 *}$, Carolina Tovar ${ }^{2}$, Thomas R. Etherington ${ }^{2,3}$, Paula A. Rodríguez-Zorro ${ }^{4}$,

5 Carolina Castellanos-Castro ${ }^{5}$, Manuel Galvis Rueda ${ }^{6}$, Suzette G.A. Flantua ${ }^{1,7,8^{*}}$

6

7

$8{ }^{1}$ Natural Capital and Plant Health Department, Royal Botanic Gardens, Kew, Ardingly, West Sussex,

9 United Kingdom.

$10{ }^{2}$ Biodiversity Informatics and Spatial Analysis, Royal Botanic Gardens, Kew, Richmond, Surrey, United

11 Kingdom

12 Manaaki Whenua - Landcare Research, Lincoln, New Zealand

$13{ }^{4}$ Institut des Sciences de l'Évolution Montpellier (ISEM), Université de Montpellier, Montpellier, France

$14{ }^{5}$ Ciencias Básicas de la Biodiversidad, Instituto de Investigación de Recursos Biológicos Alexander von

15 Humboldt, Bogotá, Colombia

$16{ }^{6}$ Departamento de Biología, Grupo de Investigación en Estudios Micro y Macro Ambientales

17 (MICRAM), Universidad Tecnológica y Pedagógica de Colombia, Tunja, Colombia

$18{ }^{7}$ Institute for Biodiversity \& Ecosystem Dynamics, University of Amsterdam, Amsterdam, The

19 Netherlands

20

${ }^{8}$ Department of Biological Sciences, University of Bergen, Bergen, Norway

21

22

23

* Corresponding authors:

Mauricio Diazgranados ${ }^{1}$

24 Millennium Seed Bank, Royal Botanic Gardens Kew, Ardingly, West Sussex, RH17 6TN, UK

25 Email address: M.Diazgranados@kew.org

26

27

28

29

30

31
Suzette Flantua ${ }^{1,7,8}$

University of Bergen, PO Box 7803, 5020 Bergen, Norway

Email address: S.G.A.Flantua@gmail.com 


\section{ABSTRACT}

33 Background. The páramos, the high-elevation ecosystems of the northern Andes, are well-known for

34 their high species richness and provide a variety of ecosystem services to local subsistence-based

35 communities and regional urbanizations. Climate change is expected to negatively affect the provision of

36 these services, but the level of this impact is still unclear. Here we assess future climate change impact on

37 the ecosystem services provided by the critically important páramos of the department of Boyacá in

38 Colombia, of which over $25 \%$ of its territory is páramo.

39 Methods. We first performed an extensive literature review to identify useful species of Boyacá, and

40 selected 103 key plant species that, based on their uses, support the provision of ecosystem services in the

41 páramos. We collated occurrence information for each key species and using a Mahalanobis distance

42 approach we applied climate niche modelling for current and future conditions.

43 Results. We show an overall tendency of reduction in area for all ecosystem services under future climate

44 conditions (mostly a loss of $10 \%$ but reaching up to a loss of $40 \%$ ), but we observe also increases, and

45 responses differ in intensity loss. Services such as Food for animals, Material and Medicinal, show a high

46 range of changes that includes both positive and negative outcomes, while for Food for humans the

47 responses are mostly substantially negative. Responses are less extreme than those projected for

48 individual species but are often complex because a given ecosystem service is provided by several

49 species. As the level of functional or ecological redundancy between species is not yet known, there is an

50 urgency to expand our knowledge on páramos ecosystem services for more species. Our results are crucial

51 for decision-makers, social and conservation organizations to support sustainable strategies to monitor and

52 mitigate the potential consequences of climate change for human livelihoods in mountainous settings.

\section{INTRODUCTION}

55 The Andean páramos occupy the highest ridges and plateaus of the Northern Andes - often called the 56 Andean sky islands (Flantua et al., 2019; 2020), and are dominated by grasslands, rosettes and bushes, 57 with an exceptionally high local endemism. Located above the upper forest line in the tropical Andes 58 (3000-3200 meters above sea level; $\mathrm{m}$ a.s.l.) and below the snowline, they are recognized as the world's 59 most diverse high-elevation ecosystem (Luteyn, 1999; Sklenáŕ et al., 2014; Rangel-Ch, 2000). They

60 provide fundamental ecosystem services to communities on a local, regional and national scale. For

61 instance, the páramos are considered the headwaters of South America by collecting, storing, and

62 supplying freshwater (Buytaert, Cuesta-Camacho \& Tobón, 2011; Nieto, Cardona \& Agudelo, 2015) for

63 an estimated 40 million people (Josse et al., 2009). Large cities, such as Bogotá and Medellín (Colombia), 
64 Quito and Cuenca (Ecuador), Piura and Cajamarca (Peru), depend on the páramos for over 80\% of their 65 fresh water supply (Rodríguez-Morales et al., 2014). In addition, the páramos function as carbon stocks 66 (Hribljan et al., 2016; Maldonado, 2017), and provide cultural needs (Farley \& Bremer, 2017), among 67 other ecosystem services. Hundreds of the more than 4,700 páramo plant species are frequently used by 68 locals as source of medicines, food, spices and condiments, construction materials, firewood, etc. (de la 69 Torre et al., 2008). However, studies that describe the provision of services at a species level are scarce, 70 e.g., pollination (Berry \& Calvo, 1989) and hydrological functioning of Espeletia spp. (Cárdenas et al., 71 2017), and very few studies have addressed the question of how key ecosystem services in the páramos 72 could be impacted by climate change.

The páramos are being negatively affected at an alarming pace due to changes in climate, land 74 use strategies and over-exploitation (Castaño-Uribe C, 2002; Anderson et al., 2011; Young, Young \& 75 Josse 2011; Tovar, Seijmonsbergen \& Duivenvoorden, 2013a; Pérez-Escobar et al., 2018). Increased 76 temperatures and changes in rainfall patterns have already caused an upward shift of the lower limit of the páramos in some areas (Morueta-Holme et al., 2015), and future projections suggest significant impacts on some of the most iconic plant species (Mavárez et al., 2018; Peyre et al. 2020; Valencia et al., 2020), and a possible reduction of its extent by c. $50 \%$ in the coming three decades (Tovar et al., 2013b). As a result, it is projected that at the species level, between 10 and $47 \%$ of Andean endemic species could go extinct by the year 2100 (Malcolm et al., 2006). In addition, fluctuations in precipitation patterns and the loss of glaciers (Vuille et al., 2008; 2018; IDEAM, 2012) are expected to significantly affect water availability for the páramos and for human consumption, agriculture and energy generation, among other ecosystem services (Castaño-Uribe, 2002; Cuesta-Camacho et al., 2008; Chevallier et al., 2010; Buytaert, Cuesta-Camacho \& Tobón, 2011; Young, Young \& Josse, 2011). The rich variety of ecosystem services related directly to uses by local communities, such as provision of agrobiodiversity and wild harvest medicinal plants, and spiritual values, is under threat of a disruptive change of significant magnitude with future climate scenarios (Anderson et al., 2011).

Because of the paramount importance of páramo ecosystem services for livelihoods, it is imperative to quantify the likely impact of climate change on the páramo plants that supply ecosystem services. In this study, we analyse climate change impact on ecosystem services provided by the páramos of the department of Boyacá (Colombia), by associating regional uses of key species to the ecosystem services they provide, and by modelling their current and future potential distributions. We selected 103 key species based on their uses and ecological roles associated with ecosystem services and geographical extent. We hypothesise that trade-off patterns will be observed where certain ecosystem services will increase and other decrease. More specifically, we postulate that provisioning and regulating services will 97 have the sharpest changes, both positive and negative (Alternative Hypothesis - $\mathrm{Ha}$ ), related to changes 
98 in hydrological conditions expected to occur under warming climate conditions (Anderson et al., 2011;

99 Buytaert, Cuesta-Camacho \& Tobón, 2011). Additionally, we hypothesise that ecosystem services related 100 to the provision of raw materials will possibly see an increase as the result of environmental changes $(\mathrm{Ha}$ 101 2), based on observed upward migration of species from lower elevations (Feeley et al., 2011; Zimmer et 102 al., 2018), which are usually woodier (i.e., shrubs and trees) and have more biomass (Sevink et al., 2014).

103 Therefore, woody taxa will likely benefit and expand their ranges to higher elevations (Young et al., 104 2017), potentially at the cost of the population size of herbaceous taxa (Feeley \& Silman, 2010).

105 This study will contribute to understanding which ecosystem services could be most affected and 106 at what magnitude, to inform decision makers and conservation/social organizations about the potential 107 impacts on livelihoods. In addition, the results are aimed to be used by government and conservation 108 organizations to register risks for natural capital assets, that will allow further monitoring and follow-up 109 on future scenarios, as well as climate change mitigation and ecosystem-based adaptation for the future 110 wellbeing of Andean communities.

\section{MATERIALS \& METHODS}

\section{Study area}

114 Colombia is known for its rich Andean topography of three mountain ranges ('cordilleras') that split in

115 the southern area of the country with the Ecuadorian border and of which the Eastern Cordillera continues

116 farther north towards the Venezuelan border (Fig. 1). Páramos are present in all cordilleras at elevations

117 beyond the upper forest line, but the largest extent is found in the Eastern Cordillera. Here, the department

118 of Boyacá has a prominent part of its territory covered by páramos (Fig. 1. 25\%;5,384 km²), with six

119 páramo complexes (i.e., groups of páramos with shared biogeographic history), of which those of the

120 Sierra Nevada del Cocuy and the Tota, Bijagual, Mamapacha complex are the largest, c. 2000 and 1500

$121 \mathrm{~km}^{2}$ respectively. The area of Boyacá's páramos represent $24 \%$ of Colombia's páramos and $10 \%$ of the

122 world's páramos. However, only a quarter of the Boyacá páramos are protected under the national

123 legislation of national parks (PNN) of which three are present in the department (Fig. 1). Despite the

124 creation in recent years of various regional nature reserves and the government programme of

125 delimitation of Colombian páramos, agricultural expansion, man-made fires and mining are notable

126 threats to this ecosystem in Boyacá (Pérez-Niño \& Leguizamón-Arias, 2020).

The páramos of Boyacá are extremely biodiverse: they currently hold 2,354 known plant and

128 lichen species, classified in 806 genera and 243 families (Table 1). This is nearly half of the 4,646 species

129 of plants and lichens reported for their entire department. Circa 1,500 are flowering plant species, and the 
130 families Asteraceae, Poaceae and Orchidaceae count for more than one third of the diversity (305, 141

131 and 76 species, respectively). Remarkably, 45 families have only one or two species, but some of them

132 form extensive populations (e.g., Drimys granadensis L.f., Polylepis quadrijuga Bitter, Weinmannia

133 tomentosa L.f.). The most diverse genera in the páramos of Boyacá are Espeletia (Asteraceae, 40 spp.),

134 Miconia (Melastomataceae, 36 spp.), Elaphoglossum (Dryopteridaceae, 35 spp.), Campylopus

135 (Dicranaceae, 32 spp.) and Cladonia (Cladoniaceae, 29 spp.). Most of the páramo species are still native 136 (2,243 spp., 95\%), and 399 are endemic to Colombia. Interestingly, although herbs account for most of 137 these páramos diversity (917 spp.), there are also 86 species of trees, 422 of shrubs and 69 of vines and

138 lianas. Despite the high diversity of these páramos, each area of continuous páramo has a relatively low 139 number of species, many of them endemic to those areas. Therefore, páramos do not share many species, 140 and very few species are broadly distributed. The number of plant species found in each páramo varies 141 depending on its geographic extent, environmental range and climatic conditions, and species numbers 142 vary from a few dozen to a few hundred, with fewer taxa shared among them (Jiménez-Rivillas et al., 143 2018; Londoño, Cleef \& Madriñán, 2014; Urgiles et al., 2018).

144 We defined our study area by using a $1000 \mathrm{~m}$ a.s.l. isoline that encloses the páramos of Boyacá

145 and part of the Eastern Cordillera towards the north and south of the Boyacá department borders (Fig. 1;

146 Supplemental Fig. S2). Our study area encompasses lower elevations as several páramo species cover

147 elevational gradients lower than the páramo itself. By doing this, we were able to use species occurrences

148 in those elevations, to produce more robust species' models and predictions (e.g., a species typical from

149 lower elevations with narrower populations in the páramo may respond positively to climate change in

150 this ecosystem, while a species typical from the páramo with no individuals found at lower elevations

151 may display a negative response).

152

153 Database of uses and ecosystem services

154 To identify ecosystem services provision by páramo plant species, we first created a database of páramo

155 plants of Boyacá with their uses, which were identified by reviewing international peer-reviewed

156 literature (using online databases such as Science Direct, Web of Science and JSTOR), and national

157 literature from universities, research institutes and local authorities and NGOs (Fig. 2; Supplemental

158 Table S1). Data sources were searched using five keywords: páramos, ecosystem services, uses, traits and

159 Boyacá. We aimed specifically at literature describing uses in Boyacá, followed by literature describing

160 uses in Colombia, having at the end 26 data sources which include books, scientific articles, reports,

161 databases, guides and conference abstracts. Uses were then categorised following Cook (1995) using a

162 level 1 and 2 classification (Supplemental Table S2). Next, we defined a set of 19 ecosystem services

163 grouped in 4 main categories, namely: (i) regulating (agroforestry, biological control, erosion regulation,

Peer) reviewing PDF | (2020:10:54631:1:0:NEW 12 Mar 2021) 
164 pollination, restoration, water regulation), (ii) provisioning (food for animals, gene sources, food for

165 humans, material, medicinal), (iii) supporting (barriers/windbreakers/support, conservation, nutrient

166 cycling, ornamental resources, soil formation) and (iv) cultural (leisure, magic or religious, social), and

167 assigned the identified uses to the different services.

168 Here we make three assumptions:

1) Useful plants, as ecosystem service providers, can be used to infer the status of those ecosystem services. Therefore, it is considered that modelling the impact of climate change on plant species can inform the impact on each of the ecosystem services they correspond to

However, we do expect that there will be a relatively high contribution of ecosystem services related to it is the most frequently reported plant use worldwide (Diazgranados et al, 2020a).

2) Changes on the spatial breadth of the species' environmental niche can be used to infer changes on the conservation status of the species' populations, and consequently also on the magnitude of the ecosystem services provided. This implies that species populations cannot adapt to the new environmental conditions.

3) The collected information on species and ecosystems sufficiently represents the variation of ecosystem services found in páramo plants.

\section{Species selection, species occurrences and climate data}

We aimed to select more than 100 species from our compiled database of useful plants of Boyacá following first three main criteria per species:

1) At least one use described within the Boyacá department.

2) The main species habitat is the páramo or is frequently reported in the páramo.

191

192 We obtained a preliminary list of c. 130 species after applying criteria 1-3 and then collected geo-located records for those species from online databases (https:/www.gbif.org/, http://biendata.org/, and https://sibcolombia.net/), to identify those with at least 20 records ( $4^{\text {th }}$ criterion). We used only those records within the Americas and records falling in the sea or outside their assigned countries were eliminated. Additionally, elevation was calculated based on the provided coordinates using the global 
198

199

200

201

202

203

204

205

206

207

208

209

210

211

212

213

214

215

216

217

218

219

220

221

222

223

224

225

226

227

228

229

230

231

differences were checked in Google Earth and species with numerous erroneous localities flagged for manual elimination. This resulted in a final list of 103 species (Supplemental Table S3) having between 18 to 2,229 reliable locations. The species nomenclature followed the taxonomic backbone of ColPlant A (http://colplanta.org/; Diazgranados et al., 2020b).

The 103 species selected for this study comprise ten habits or growth forms: upright shrub (35.92\% of the species), upright herb (20.39\%), basal rosette $(13.59 \%)$, tree $(7.77 \%)$, prostrate herb $(5.83 \%)$, stem rosette $(5.83 \%)$, tussock (3.88\%), prostrate shrub $(2.91 \%)$, cushion/mat forming $(1.94 \%)$ and trailing herb (1.94\%) (Supplemental Table S3). All the species are found in the páramos, either in the low- and mid-páramo, approx. below 4,100 m a.s.1. (98.1\%) or in the super-páramo, typically above 4,100 m a.s.1. (94.1\%) (elevation belts sensu León, Jiménez \& Marín, 2015). Most species (75.7\%) extend their geographic range down to the Andean forest, below 3,000 m a.s.l. (e.g., shrubs from the low-páramo that can be found in the Andean forest in lower frequencies), but only seven species of them thrive in them (e.g., trees that can be found indistinctly in either the high-Andean forest or the low-páramo). Six species have not been reported in the super-páramo, and 25 species cannot be found in the Andean forest. In some cases, typical páramo species (e.g., Espeletia boyacensis Cuatrec., E. congestiflora Cuatrec.) can be found at lower elevations because of the paramisation effect (i.e. transformation of the Andean forest into páramo vegetation after disturbance) or the presence of azonal páramos (e.g. in poorly drained basins or high-Andean forest).

For the climate data $(\sim 1960-1990)$ we used the 30 arc-second resolution 19 bioclimatic variables from WorldClim version 1.4 (Hijmans et al., 2005). For future climate projections we used the same biovariables for each available global circulation model (GCM), which provided predictions for: relative concentration pathway (RCP) values of 2.6, 4.5, 6.0, and 8.5; and for both the 2050 and 2070 time periods. Climatic values for all 19 bioclimatic variables were extracted for each species observation, and excluded repeated observations of the same species within the same climate cell such that there was only one species observation per climate cell.

\section{Current and future climate niche modelling}

We began our analyses by recognising that many of the 19 bioclimatic variables from WorldClim are highly correlated and that some of the variables may be less relevant to our study area. Principal components analysis (PCA) is a dimensionality reduction technique for eliminating redundancy of correlated variables (Pearson, 1901; Hotelling, 1933a; Hotelling, 1933b). This method has a longstanding tradition in niche studies for describing environmental space with a minimal set of independent axes (James, 1971). As PCA can be applied to raster geographic information system (GIS) surfaces

(Demšar et al., 2013), it can be used, for instance, to create an environmental niche space from 
232 WorldClim data (Soberón \& Nakamura, 2009). Here, we fitted a PCA for all 19 bioclimatic variables

233 using the 57,665 1- $\mathrm{km}^{2}$ raster cells that defined our study area. In doing so we first pre-processed the

234 climate data to ensure it was suitable for PCA (Nguyen \& Holmes, 2019). We log-transformed all rainfall

235 variables so that all 19 bioclimatic variables had unimodal and not overly skewed distributions. Then all

236 variables were centred and scaled by transformation to z-scores. From our interpretation of the PCA

237 loadings, the first three components primarily captured variation in temperature, moisture, and their

238 combined seasonality, which together explained $86 \%$ of the climatic variance. We decided to limit our

239 description of environmental space to the first three principal components as the fourth to nineteenth

240 principal components only explained small amounts of further variance. Additionally, the variance

241 explained by these components did not have a clear pattern, which would suggest that the variation being

242 explained may be primarily noise in the data. All climatic data was then transformed into an

243 environmental space defined by the first three principal components (see animated Supplemental

244 Figures S2).

On the assumption that the actual distribution of species that are valuable for ecosystem services could be modified by humans through propagation and assisted dispersal, rather than trying to understand where species actually occurred, which would be affected by land use practices, we were solely interested in understanding at the broad spatial scale of our study area where the climatic conditions meant that they could occur. This question is best addressed by modelling the fundamental niche of a species that is "an n-dimensional hypervolume, ... which corresponds to a state of the environment which would permit the species ... to exist indefinitely" (Hutchinson, 1957, p. 416). Our choice of fundamental niche modelling methodology was heavily constrained by our species data. We did not have absence data, which precluded presence-absence methods. Also, due to the variety of data sources combined into our data set, we did not feel confident in defining a reliable background region to represent the area that was sampled, which precluded presence-background methods. Of the presence-only methods, we eliminated climatic envelope methods such as those based on convex hulls (Walker \& Cocks, 1991), as these are sensitive to outliers which we expected might be present in our data. We also excluded climatic envelope methods as they produce binary niche estimates, but we expected that "there will however be an optimal part of the niche with markedly suboptimal conditions near the boundaries" (Hutchinson, 1957, p. 417). Of the presence-only techniques producing a continuous niche estimate we also eliminated density-based methods, as these require large samples free of sampling bias (Blonder et al., 2014), which our data was not. Ultimately, we decided that given our modelling question and data, the Mahalanobis distance was the most appropriate choice (Mahalanobis, 1936; Clark, Dunn \& Smith, 1993; Farber \& Kadmon, 2003;

264 Etherington, 2019). As the Mahalanobis distance is based on a multivariate normal distribution, our 265 models of fundamental niche would be elliptical in shape (see also Soberón \& Nakamura, 2009). Also, 
266 although results vary by species, Mahalanobis distance has compared well against other presence-only, 267 presence-background, and presence-absence modelling approaches (Dettmers, Buehler \& Bartlett, 2002; 268 Johnson \& Gillingham, 2005; Tsoar et al., 2007).

269 To explore issues of model uncertainty, we generated 1,000 bootstrap resamples (Efron, 1979; 270 Diaconis \& Efron, 1983) for each species as bootstrapping has been shown to be a reliable method of 271 model evaluation (Verbyla \& Litvaitis, 1989; Etherington \& Lieske, 2019). Each bootstrap resample was 272 then used to create a separate Mahalanobis distance model of the fundamental niche, with Mahalanobis 273 distances converted to chi-square probabilities of being within the fundamental niche (Etherington, 2019).

274 This resulted in each species having 1,000 different possible fundamental niches that varied in location, 275 size, and orientation within environmental space (Fig. 3a-c). Each bootstrap fundamental niche was then 276 used to map within our study area each species' potential niche, which is "the intersection of the 277 fundamental niche with the realized environmental space at a particular time" (Jackson \& Overpeck, 278 2000, p. 197). When done for the current climate data this meant that each species would have 1,000 279 maps of potential niche representing the probability that areas have climate conditions that could support 280 the species. The total area of potential niche for each bootstrap resample was then calculated as the sum 281 of all cells' niche probability value (Fig. 4a). As the potential niche of a species within a region will 282 change as the environment changes (Jackson \& Overpeck, 2000; see animated Supplemental Figures S3, 283 S4), the potential niche area for each bootstrap fundamental niche was also calculated for each

284 285 286 287 288 289 290 291 292 293 294 295 296 297 298 combination of the 2050 and 2070 time periods and for the RCP 2.6, 4.5, 6.0, and 8.5 scenarios. For each combination of time period and RCP scenario, future climate predictions were selected randomly from the 10 GCMs that had data for all combinations (Fig. 4b-i). Although we acknowledge that some GCMs may be more appropriate for our study area, we have followed the Intergovernmental Panel on Climate Change by assuming that each GCM is equally valid (Maslin, 2014), and as such we selected from the 10 GCMs randomly for each future potential niche. This process ultimately resulted in 1,000 estimates of potential niche area for each species for current climate conditions, and for the eight factorial combinations of the two future time periods and the four RCPS.

The bootstrap predictions of potential niche area were then combined by ecosystem service and converted into percentages of the study area. Changes in ecosystem service potential niche area between the present and all future climate combinations were presented as in terms of changes in percentage points. Preliminary analyses demonstrated that the distributions of potential niche areas were extremely complex and highly variable (Fig. 4), and therefore could not be reliably and consistently described using summary statistics. Therefore, we chose to use beanplots (Kampstra, 2008) as a method for visualisation and interpretation changes in potential niche area. 

using the NumPy (van der Walt, Colbert \& Varoquaux, 2011), GDAL (Warmerdam, 2008), and Pandas (McKinney, 2013) packages. Statistical analysis and plotting were programmed in R (R Core Team, 2018) using the beanplot (Kampstra, 2008), raster (Hijmans, 2018), fields (Nychka et al., 2017), RColorBrewer (Neuwirth, 2014), rgl (Adler et al., 2018), and misc3d (Feng \& Tierney, 2008) packages.

\section{RESULTS}

\section{Uses and ecosystem services in Boyacá}

308 We associated the uses of the 103 targeted species with 19 different ecosystem services at level 2 (ES2) for the four main level 1 ecosystem services (ES1) (Supplemental Table S3; Supplemental Figure S5). ES1 with the highest and lowest number of ES2 is Regulation $(\mathrm{n}=6)$ and Cultural $(\mathrm{n}=3)$, respectively. The most common ecosystem services at level $2(\mathrm{ES} 2)$ is Medicinal $(\mathrm{n}=86)$ followed by Material $(\mathrm{n}=$ 37), Restoration $(\mathrm{n}=28)$ and Ornamental resources $(\mathrm{n}=26)$; the first two found in ES1 Provision, the latter two found in the ES1 Regulation and Support, respectively. A few ES2 were found only once or twice, such as Leisure in ES1 Culture, Genetic sources in ES1 Provision, and Agroforestry in ES1 Regulation. Species provide a median of two ES2 but some species provided up to eleven ES2 such as Macleania rupestris (Kunth) A.C.Sm. (shrub, creeper) and Vaccinium meridionale Sw. (shrub) from the Ericaceae family, and Morella parvifolia Benth. (shrub, tree) from the Myricaceae family (Supplemental Figure S5).

\section{Bioclimatic change in Boyacá}

321 We compared changes from present day to future conditions using all GCMs (Fig. 5). A comparison 322 between the position of all the future ellipses and the directionality of the loadings for the bioclimatic 323 variables shown as arrows indicates that although there is notable variation in individual GCM predictions, the trajectories of bioclimatic change are associated with increasing temperatures (BIO1, BIO5-11) and climate seasonality (BIO4 and BIO15). Therefore, as the RCP and time into the future increases, we would expect the study area to experience increases in minimum, mean, and maximum temperatures as well as greater temperature ranges, and temperature and rainfall seasonality including more extreme drier periods. These increasing temperatures and seasonality could both act as stressors on plant biology meaning that changes in potential niche will be expected. 


\section{Changes in potential niche area of plant taxa and ecosystem services}

332 At a species level, potential niche area changes are highly variable but nearly all the 103 species appear

333 more likely to decline than increase (see individual species beanplots and niche areas provided as

334 supplemental files in figshare). Only two species look likely to experience an increase in potential niche

335 area, Excremis coarctata (Ruiz \& Pav.) Baker (herb) and Juncus effusus L. (herb). Other species such as

336 Dryopteris wallichiana (Spreng.) Hyl. (fern), Myrsine coriacea (Sw.) R.Br. ex Roem. \& Schult. (shrub,

337

338

339

340

341

342

343

344

345

346

347

348

349

350

351

352

353

354

355

356

357

358

359

360

361

362

363

small tree), and Stevia lucida Lag. (shrub) could also experience a notable increase, but they could just as likely experience a decrease. Substantial losses even under the RCP 2.6 are likely for several succulent and bushy taxa, such as Echeveria quitensis (Kunth) Lindl., Eryngium humile Cav., Gaiadendron punctatum (Ruiz \& Pav.) G.Don, and Vaccinium meridionale Sw.. The four Baccharis taxa show substantial changes. A few taxa show hardly any change, even under the most pessimistic scenarios, such as Espeletia incana Cuatrec. (stem rosette), Espeletiopsis pleiochasia (Cuatrec.) Cuatrec. (stem rosette), and Lycopodium clavatum L. (moss).

After aggregating species distributions into ecosystem service distributions, it becomes evident that the most likely outcome for most, if not all ecosystem services, is a decline in potential niche area. This decline increases as the severity of the RCP scenarios increases and as the time into the future increases and is up to around 20 percentage points, and possibly even around 30 percentage points, at both ES2 (Fig. 6) and ES1 (Fig. 7).

However, there were some notable differences in potential niche area changes under future conditions, especially at the ES2 level (Fig. 6). In cases such as Food for animals, Material and Medicinal, the range of changes is high and includes both positive and negative outcomes ( $\mathrm{Ha} \mathrm{l}$ ), while in other cases such as Gene sources, Agroforestry and Food for humans the large range is mostly substantially negative. In contrast, ecosystem services such as Leisure and Biological control have much smaller ranges of possible outcomes that are constrained to a reduction of around 0-10 percentage points, with extreme values reaching $30-40$ percentage points. Also, the projections show a small possibility for a potential increase of a few percentage points for a few provision (e.g., Food for animals, Material (Ha 2), Medicinal), regulating (e.g., Erosion regulation, Pollination, Restoration, Water regulation), and supporting (e.g. Barriers/windbreaks/supports) services. Ecosystem services that are affected more by differences in the RCP scenarios are Gene sources, Agroforestry, Nutrient cycling, and Soil formation, which all show steep declines in potential niche area as RCP severity increases. Ecosystem services for which potential niche area declines more noticeable across time include Gene sources, Agroforestry, Erosion Regulation, Nutrient cycling, and Soil formation.

Peer] reviewing PDF | (2020:10:54631:1:0:NEW 12 Mar 2021) 


\section{DISCUSSION}

365 The páramos of Boyacá are projected to experience higher temperatures and increased seasonality under 366 climate change scenarios, and as a result, we show that significant changes are expected to happen by 367 2050, affecting the livelihoods of peoples depending on them. These changes will lead to an overall 368 decrease in the provision of most ecosystem services (ES1) by native species (e.g., water regulation and 369 materials). The magnitude of those changes is rather difficult to estimate, in part because of the lack of 370 more precise information on the services provided (e.g., lack of data on income linked to goods/species), 371 and in part because of the uncertainties regarding the plant responses to niche changes due to climate.

372 Although a few species are likely to increase their niche area, these seem not to have a great 373 effect on the overall results at ES1 level. Tendencies of change are overly negative (mostly a loss of $10 \%$ 374 but reaching up to a loss of $40 \%$ ). However, some ecosystem services and taxa showed high variability in 375 change (with both positive and negative possibilities), while those less variable were often negative. A 376 few previous studies have highlighted the effects of climate change on ecosystem services provided by 377 plants in the tropical Andes (Anderson et al., 2011), in the high Andean peatlands (e.g., Bounous et al., 378 2018) or in wetlands (e.g., Moor, Highlander \& Norberg, 2015). A recent study concluded that the regions 379 of Boyacá and Cundinamarca have experienced increased seasonality over the last 30 years (Fajardo 380 Rojas, 2019), with direct negative impacts on farming yields (Tapasco et al., 2015). However, to our 381 knowledge, this is the first study quantifying effects of climate change on ecosystem services for the 382 páramos.

As we had expected, water regulation was among the ES2 with the highest projected losses ( $\mathrm{Ha}$

384

385

386

387

388

389

390

391

392 393 394 395 396 1). Among the plants providing this service is, for instance, the Puya goudotiana Mez (Bromeliaceae), whose rosette forms a water tank (Hornung-Leoni \& Sosa, 2018) and is often suggested to contribute to the overall water storage of the páramos, as other tank-root species do in their habitats (Benzing \& Bennett, 2000; Givnish et al., 2011; Males, 2016; Zotz et al., 2020). In general, inhabitants in close proximity to the páramos perceive páramo plants as providers of water provisioning service (Laverde Martinez, 2008; Farley \& Bremer, 2017). Nevertheless, for many of the species related to this service, a clear relationship with water provisioning services remains to be analysed.

We also expected that the potential niche area of species providing materials would expand ( $\mathrm{Ha}$ 2), given that warming climate is expected to favour thermophilic woody species (Lutz, Powell \& Silman, 2013; Fadrique et al., 2018) which make up 89\% of all materials in our dataset (Supplemental Table S3). Yet, we mostly observed a decrease in potential niche area (Fig. 6), thus suggesting that rather than benefiting from increased temperatures these species could be suffering from other environmental changes. For instance, future climate projections suggest seasonality is likely to increase and extreme 
397 temperatures will be more frequent leading to a non-analogous climate to the current situation which 398 imposes challenges to all taxa independent of life form. Only very few species such as the shrub Myrsine coriacea show an increase in potential niche area, but this tendency is insufficient to avoid the overall decrease projected for materials (Table 2). Among species with the highest projected losses are also those that provide the highest number of ES2. This is the case, for example, of the shrub Vaccinium meridionale, which currently provides $11 \mathrm{ES} 2$, mostly provision (e.g., food for animals and people, materials, medicinal) and regulating services (e.g., erosion and water regulation, restoration) (e.g., Agrodiva Foundation, 2017).

The ecosystem services provided under current climate conditions will inevitably change as a result of shifting base-line climate; estimating the scale and intensity of change, however, is complex and is defined at different levels of the páramo system. The first driver of change, and at the species level, is the loss of environmental space for a species providing an ecosystem service. As a consequence, the spatial distribution of a species is reduced, resulting in a net loss of individuals providing that particular ecosystem service.

The second driver of change is a change in the biotic interactions that operates at the level of the whole food web down to each unique biotic interaction. Shifts in, and perhaps decoupling of, biotic interactions are expected as a result of changes in the community disassembly, more so in tropical mountains (Sheldon, Yang \& Tewksbury, 2011). For example, recent reports have documented new fungi-insect-plant interactions severely affecting local populations of páramo plants such as numerous species of Espeletia (Medina et al., 2010). Also, it has been suggested that the introduction of invasive species associated with pastures (e.g., Anthoxanthum odoratum L., Poa annua L., Holcus lanatus L., and Cenchrus clandestinus (Hochst. ex Chiov.) Morrone) and agricultural systems (e.g., Rumex acetosella L. and Hypochaeris radicata L.) reduce the local biodiversity and the offer of ecosystem services (GutiérrezBonilla et al., 2017).

The third driver of change is the result of the degree of functional compensation, or ecological redundancy, among species (see Rosenfeld, 2002a; Rosenfeld, 2002b). It might be that substantial loss in future ecosystem services provision might be less than expected due to several species playing equivalent roles in the ecosystems, i.e. they are ecologically redundant (Morelli \& Tryjanowski, 2016). Our results show that the projected changes of ecosystem services in Boyacá are less extreme than previous studies suggest based on the expected reduction in general for Andean species (e.g., Ramirez-Villegas et al., 2014) and the páramo biome (e.g., Tovar et al., 2013b). Given that an ecosystem service at ES2 is provided by several species, one explanation to the lower than expected change could be a certain degree of "compensation" or replacement between different species responses. Considering the extremely rich high elevation flora of the páramos, this could be a possibility. However, it is unlikely that species fulfil 
431 exact functional replicates of each other, and our understanding is far from grasping the complexity of

432 biotic interactions on a multidimensional level of natural ecosystems (Morelli \& Tryjanowski, 2016).

433 Thus, the overall tendency indicates losses of ecosystem services across the different levels and scales,

434 but these are less dramatic than previously suggested in large scale studies at species and biomes levels,

435 but the exact causes are challenging to decipher.

436 Our results show that species are projected to suffer a reduction in their niche, which will likely

437 affect floristic composition in the páramos of Boyacá and thus their ecosystem services. This is not

438 surprising as evidence shows that upslope displacement of "alpine" species has occurred in the northern

439 Andes in the last 200 years (Morueta-Holme et al., 2015; Moret et al., 2019). Also, Andean forest

440 communities are already showing changes towards species with higher thermal optimum

441 (thermophilisation) across the Andes in the last 15 years (Fadrique et al., 2018). Therefore, it is possible

442 that thermophilisation might also be occurring in the páramo, however this remains to be tested. In the

443 upper end of the páramo, colonization of newly deglaciated areas is occurring (Cuesta et al., 2019) but

444 might show a lag in response (Zimmer et al., 2014; Zimmer et al., 2018). At the lower end, some species

445 from the upper Andean forest could potentially be colonising the páramo and could provide some of the

446 ecosystem services that were provided by the native species. However, some ES2 could be greatly

447 affected by these compositional changes (Sheldon, Yang \& Tewksbury, 2011) because specialization is

448 thought to be greater in the tropics (Dyer et al., 2007). Asynchronous range shifts resulting in a

449 community disassembly could thus, cause the introduction of novel interactions that either benefit or

450 jeopardize the páramo’s functioning as a system (Larsen et al., 2011; Sheldon, Yang \& Tewksbury,

451 2011). However, further analyses are needed on páramo species interactions in relationship to ecosystem

452 services provided.

453 Our estimates of potential niche area change often had large ranges from around +10 to -40

454 percentage points at both ecosystem service level two (Fig. 6) and level one (Fig. 7). These large ranges

455 of uncertainty could have resulted in part from variations in fundamental niche estimates resulting from

456 bootstrap resampling (Fig. 3) that created variations in potential niche (Fig. 4a). A more significant

457 source of uncertainty is likely derived from differences in future climate estimates from different GCMs

458 which often produced very different future estimates of potential niches (Fig. $\mathbf{4 b}-\mathbf{i}$ ). This is not surprising

459 as mountain climates are hard to predict, and given the lack of guidance on choosing GCMs, it remains

460 very important to use many GCMs to try and capture the full uncertainty of future climatic conditions

461 (Beaumont et al., 2008). Also, the potential niche estimates could overestimate area as the realised niche

462 resulting from biotic interactions such as competition will result in a realised niche that is smaller than the

463 potential niche (Jackson \& Overpeck, 2000). Likewise, it is important to note that the area of actual

464 distribution will be much smaller again due to dispersal constraints limiting the areas that are or have 
465 been accessible to a species (Soberón \& Nakamura, 2009). Also, while the scale of our modelling is 466 appropriate given the extent of our study area, we acknowledge there will be microclimatic effects from 467 topography operating below the $1 \mathrm{~km}^{2}$ grain of this study that will further affect the distribution of the 468 potential niche at the scale of an individual plant (Lembrechts et al., 2019).

Our literature review provided insights into the numerous ecosystem services provided by páramo

470

471

472

473

474

475

476

477

478

479

480

481

482

483

484

485

486

487

488

489

490

491

492

493

494

495

496

497

498 species and those species that have a multi-functionality in terms of ecosystem services provision. The frequency of uses of the 103 species selected is somehow expected, i.e., most uses are linked to medicinal $(n=86)$, materials $(n=37)$, restoration $(n=28)$ and ornamental resources $(n=26)$. A similar pattern has been observed in the World (UPW) and Colombian (UPC) datasets of useful plants (Diazgranados et al., 2020a). In our study, $83.5 \%$ of the selected species had medicinal uses, compared to $78.7 \%$ of the UPC and $66.2 \%$ of the UPW. Similar percentages are obtained for materials $(35.6 \%$ this study, $32 \%$ UPC; $33.4 \% \mathrm{UPW}$ ); and environmental use (restoration plus ornamental resources; $27.2 \%$ this study, $27.5 \%$ UPC; $22.3 \%$ UPW).

However, some remarks are needed that further research could address building on the outcomes here presented. First of all, we collected and curated information for 103 species with corresponding georeferenced information. This number covers $23 \%$ of the estimated number of useful species hosted by the páramos of Boyacá (i.e., compared to 451 useful species reported for Boyacá's páramos by the Instituto de Investigación de Recursos Biológicos Alexander von Humbodlt, 2014). Notwithstanding that it would be preferable to include more species, many individual páramo areas have between a few dozen and a few hundred species, with fewer being shared among them (Jiménez-Rivillas et al., 2018; Londoño, Cleef \& Madriñán, 2014; Urgiles et al., 2018). Including more narrowly distributed species adds little weight to the provision of ecosystem services, and poses at least three challenges for modelling: 1) the scale of the climatic data precludes the inclusion of species with narrow distributions, as often they lack enough data points to inform the models; in fact, we had to discard 27 species because of redundant data points falling within the same grid cells of analysis; 2) narrowly distributed species often have very few georeferenced records; and 3) they cannot be used for finding patterns at larger scales, e.g. for the páramos of Boyacá.

In many cases, uses and their associated ecosystem services are unknown for species, thus relying on a still limited but slowly growing field of research. This inevitably results in a limited number of taxa per ecosystem service and a skew towards those ecosystem services most commonly studied, such as medicinal uses and materials (see also Diazgranados et al., 2020a). The addition of more species to the results here presented may as likely provide a more positive scenario of future predictions (by including more resilient species) as a more pessimistic scenario (by including more sensitive species). The results need to be interpreted in the context of the species included, and it is important to acknowledge that the 
499

500

501

502

503

504

505

506

507

508

509

510

511

512

513

514

515

516

517

518

519

520

521

522

523

524

525

526

527

528

529

530

531

results for ecosystem services with fewer species may be open to more change if many other species were added. However, only the inclusion of more species relying on a larger dataset and expanding literature may predict which way things could change.

For the páramos in particular, there is a daunting lack of understanding on the functionality of species within the community, let alone the functioning of the food web as a whole, precluding a better understanding of the species traits contributing to ES. Important contributions are currently being made to estimate páramo plant properties, such as freezing resistance, water relations, gas exchange characteristics (Rada, Azócar \& García-Núñez, 2019), soil temperature regulations (Mora, Llambí \& Ramírez, 2019), leaf water potential (Sandoval, Rada \& Sarmiento, 2019), pollination (Pelayo et al., 2019), evapotranspiration (Rodríguez-Morales et al., 2019), dispersal strategies (Tovar et al., 2020), and biomass (Cabrera, Samboni-Guerrero \& Duivenvoorden, 2018; Cabrera \& Duivenvoorden, 2020). Though relevant base-line knowledge, with such approaches alone will be a huge endeavour to cover a representative proportion of the c. 4,700 plant species currently identified for the páramo (Luteyn, 1999; Sklenáŕ et al., 2005; Rangel-Ch, 2000). The multi-functional landscape of the páramos requires monitoring schemes of high technology (e.g. hyperspectral drone remote sensing; Borrelli et al., 2015; Zhang et al., 2020) and the inclusion of local knowledge (UICN, 2015), which need to be integrated at an overarching centralized level (see for instance the PARAGUAS project (2019-2021) (https://paraguas.ceh.ac.uk/)). Multi-disciplinary projects supported by strong collaborations between national universities and institutes should prioritize knowledge sharing through open-access platforms. An example is the digitized online system of biodiversity in Colombia (SIB, for Sistema de información sobre biodiversidad de Colombia; https://sibcolombia.net/), where also an increasing number of protocols are published, for instance to measure species traits.

\section{RECOMMENDATIONS}

To improve the livelihoods of people that depend on the páramo's ecosystem services and thus are the first to suffer the consequences of climate change, several knowledge gaps need to be addressed. First of all, we are certain that the current lists of species known to occur in the páramos of Boyacá and Colombia are still incomplete, though major efforts have been undertaken recently (e.g., Diazgranados, 2012; Sylvester et al., 2020). Secondly, research focused on describing the functionality of species within the páramo community as a whole is pivotal but scarce. These gaps are at the frontline of scientific research but, considering the urgency and the expected velocity of temperature increase, outcomes from such research could potentially take decades to deliver and thus miss being included in the crucial development of current conservation management plans. Therefore, we outline several action items for prompt 
532 implementation by local governments (i-iii) and researchers engaged in studying the páramos under

533 different climate conditions (iv):

534 (i) First, monitoring, monitoring and monitoring. It is of absolute critical value to monitor

535 currently known functional properties of the páramo, even though we are not certain yet which taxa

536 contribute most. This includes monitoring the productivity of the páramos in terms of hydrology (e.g.

537 Cárdenas \& Tobón, 2017). Permanent monitoring stations need to be installed and of access to the general

538 public to allow capturing smaller changes occurring before a larger change is imminent and to help a

539 community-based effort to adjust management plans when such changes are observed. Monitoring

540 changes in plant composition and abundances in permanent plots are of crucial relevance to detect early

541 warning signs of loss of taxa, invasive species and thermophilisation of the páramo. An expansion of the

542 current network of GLORIA (https://redgloria.condesan.org; Cuesta et al., 2017) would provide the

543 implementation of a consistent methodology over a larger region, but several methods are of equal value

544 (Llambí et al., 2020). Additionally, a replicate study to this current study but implemented for the Andean

545 forest will help to provide predictions whether species possibly migrating upwards to the páramo could be

546 contributing or jeopardizing the provision of ecosystem services.

547 (ii) The involvement of local stakeholders to estimate how often people access the ecosystem

548 services and how much resources are used. Building an open-access baseline database by the local

549 communities of plant uses in relation to ecosystem services, not only contributes to monitoring essential

550 taxa but also contributes to the establishment and recognition of the cultural heritage of a region.

551

(iii) Disseminate the knowledge and engage society about the importance of the páramo

552 ecosystem and its plants in people's lives. The monitoring efforts are unlikely to improve people's

553 livelihoods unless their results are clearly communicated, and results are centralised and made available

554 to the public.

555

(iv) Ideally, fundamental niche models should be trained using not only present-day information, but also with information from the past for various reasons (Collevatti et al., 2013; Ordonez \& Williams, 2013; Fitzpatrick et al., 2018). First of all, humans have altered the realized niche space for a range of different organisms (Albuquerque et al., 2018) either constraining (e.g., habitat destructions) or amplifying (e.g., invasive species), hampering the reconstruction of the fundamental niche space. Studies

560 in the high tropics are few but such as those by Brugger et al. (2019) show the high potential legacy effect of past humans in high elevation Andean systems. However, more research in tropical ecosystems is

562 needed to understand the possible subtle changes humans left in present-day species composition

563 (McMichael, 2020). Secondly, palaeoecological reconstructions of the páramos have shown that the

564 current interglacial, warm conditions are forcing these systems to be in a highly truncated spatial

565 distribution in comparison to their 'normal' configuration, where the páramos occupied extensive area 
566 throughout the northern Andes (Flantua \& Hooghiemstra, 2018; Flantua et al., 2019). For this same

567 reason, it is likely that any study predicting future distributions of high mountain taxa are faced with a

568 limited set of information to base the fundamental niche on. This has been flagged as critical in the usage

569 of niche modelling (Maguire et al., 2015; Nogués-Bravo, 2009; Varela et al., 2011) but it would require a

570 strong palaeoecological and macroecological approach which is currently still missing for the Andes, and

571 many mountains around the world.

572

\section{CONCLUSIONS}

574 Our study represents one of the first attempts to quantify the impact of climate change on various

575 ecosystem services of the páramos in general, by estimating the potential effects on plants contributing to

576 them. The páramos of Boyacá are projected to experience higher temperatures and increased seasonality

577 under climate change scenarios. As a result, species are projected to suffer a reduction in their potential

578 niche, which will likely affect floristic composition in the páramos of Boyacá ant thus the provision of

579 ecosystem services by native species. The projected changes of ecosystem services in Boyacá are less

580 extreme than previous studies suggest based on the expected reduction in general for Andean species and

581

582

583

584

585

586

587

588

589

590

591

592

593

594 595 the páramo biome. Nevertheless, these changes may affect local inhabitants relying on them.

Tendencies of change are overly negative (mostly a loss of $10 \%$ but reaching up to a loss of $40 \%$ ) with some ecosystem services and taxa showing high variability in change (with both positive and negative possibilities) with others less variable though often still negative. As we had expected, water regulation was among the ES2 with the highest projected losses. Contrary to what we had hypothesised, we mostly observed a decrease in potential niche area of species related to provision of raw materials, thus suggesting that rather than benefiting from increased temperatures these species could be suffering from other environmental changes (e.g., increased climate seasonality).

Some predicted impacts on the ecosystem services may change social and economic dynamics of local communities, transforming the region in unexpected ways and affecting livelihoods of peoples. Therefore, we urge government, academia and conservation organizations to create a baseline on the social and economic links to ecosystem services, and to register risks for natural capital assets. This will allow further monitoring and follow-up on future scenarios, as well as climate change mitigation and ecosystem-based adaptation for the future wellbeing of Andean communities. 


\section{ACKNOWLEDGEMENTS}

597 This project was part of the "Kew-Colombia Bio Programme" (2016-2020), which supports the 598 development of primary research on biodiversity and ecosystem services in parts of Colombia with 599 substantial voids in knowledge, to support the green growth of the country. We are very grateful to the 600 Foreign \& Commonwealth Office (FCO) - Colombia and the British Embassy in Colombia, for their 601 support on this programme. We thank the Instituto de Investigación de Recursos Biológicos Alexander 602 von Humboldt (IAVH) for their support and collaboration in Colombia, as well as the Universidad 603 Pedagógica Tecnológica de Colombia (UPTC). We are very grateful to Herman Amaya from the 604 Gobernación de Boyacá, to the Corporación Autónoma Regional de Boyacá (CorpoBoyacá), to Parques 605 Nacionales Naturales de Colombia, to Julián Barbosa from the Corporación Tibaira and to Maria Eugenia 606 Morales from the UPTC, for facilitating various aspects of this project; to our local guides in the páramos 607 of Boyacá: José Castellanos, William Gómez, José Ramiro García, Nicomedes Hernández and Juan 608 Ponguta; to our students assisting us in the field and with the database: Andrea Simbaqueba, David 609 Estéban Granados, Carlos Andrés Albarracín, Laura Pinzón, and Andrés Felipe Bohórquez; to Carolina 610 Gómez Posada, Andrés Cuervo and Hernando García from the IAVH; and to Tiziana Ulian from RBG

611 Kew, for her constant support. We also thank Elizabeth Aguilera and Georg Karl Weber from the

612 Agrodiva foundation for their information about the uses of páramo plants

613 (https://sites.google.com/site/fundacionagrodiva/home). Funds to this project were received from BEIS as

614 part of a binational collaboration between the UK and Colombia, where Colombian partners are being

615 funded by regional governments through the national royalties' system (Sistema General de Regalías, 616 SGR) and by the Administrative Department of Science, Technology and Innovation of Colombia 617 (Colciencias).

618

\section{REFERENCES}

620

621

622

623

624

625

626
Adler D, Murdoch D, Nenadic O, Urbanek S, Chen M, Gebhardt A, Bolker B, Csardi G, Strzelecki A, Senger A, Eddelbuettel D. 2018. rgl: 3D Visualization Using OpenGL. R package version 0.99.16. Available at https://CRAN.R-project.org/package=rgl (accessed 06 July 2020). Agrodiva Foundation. 2017. Fichas técnicas de frutos silvestres en zonas Andinas. Available at https://sites.google.com/site/fundacionagrodiva/file-cabinet (accessed 06 July 2020).

Albuquerque UP, Gonçalves PHS, Ferreira Júnior WS, Chaves LS, Oliveira RCdS, Silva TLLd, Santos GCd, Araújo EdL. 2018. Humans as niche constructors: Revisiting the concept of chronic

Peer] reviewing PDF | (2020:10:54631:1:0:NEW 12 Mar 2021) 
627

628

629

630

631

632

633

634

635

636

637

638

639

640

641

642

643

644

645

646

647

648

649

650

651

652

653

654

655

656

657

658

659

anthropogenic disturbances in ecology. Perspectives in Ecology and Conservation 16:1-11. DOI: 10.1016/j.pecon.2017.08.006.

Anderson EP, Marengo J, Villalba R, Halloy S, Young B, Cordero D, Gast F, Jaimes E, Ruiz D. 2011. Consequences of Climate Change for Ecosystems and Ecosystem Services in the Tropical Andes. In: Herzog SK, Martínez R, Jørgensen PM, Tiessen H, eds. Climate Change and Biodiversity in the Tropical Andes. São José dos Campos: Inter-American Institute for Global Change Research and Scientific Committee on Problems of the Environment,1-18.

Beaumont LJ, Hughes L, Pitman AJ. 2008. Why is the choice of future climate scenarios for species distribution modelling important? Ecology Letters 11:1135-1146. DOI: 0.1111/j.14610248.2008.01231.x.

Beltrán-Cuartas AM, Silva NM, Linares EL, Cardona FA. 2010. La etnobotánica y la educación geográfica en la comunidad rural Guacamayas, Boyacá, Colombia. Uni-pluriversidad 10(3): 124134.

Benzing DH, Bennett B. 2000. Bromeliaceae: profile of an adaptive radiation. Cambridge University Press.

Bernal R, Gradstein S, Celis M. 2019. Catálogo de plantas y líquenes de Colombia. Available at http://catalogoplantasdecolombia.unal.edu.co/. Instituto de Ciencias Naturales, Universidad Nacional de Colombia. (accessed 01 June 2019).

Berry PE, Calvo RN. 1989. Wind pollination, self-incompatibility, and altitudinal shifts in pollination systems in the high Andean genus Espeletia (Asteraceae). American Journal of Botany 76:16021614. DOI: 10.1002/j.1537-2197.1989.tb15145.x.

Biggs R, Schlüter M, Biggs D, Bohensky EL, BurnSilver S, Cundill G, Dakos V, Daw TM, Evans LS, Kotschy K, Leitch AM, Meek C, Quinlan A, Raudsepp-Hearne C, Robards MD, Schoon ML, Schultz L, West PC. 2012. Toward Principles for Enhancing the Resilience of Ecosystem Services. Annual Review of Environment and Resources 37:421-448. DOI: 10.1146/annurev-environ-051211-123836.

Blonder B, Lamanna C, Violle C, Enquist BJ. 2014. The n -dimensional hypervolume: The $n$ dimensional hypervolume. Global Ecology and Biogeography 23:595-609. DOI: 10.1111/geb.12146.

Borrelli P, Armenteras D, Panagos P, Modugno S, Schütt B. 2015. The implications of fire management in the Andean páramo: a preliminary assessment using satellite remote sensing. Remote Sensing 7:11061-11082.

Bounous M, Condom T, Isela Meneses R, Vincent P, Garcia C, Anthelme F. 2018. Cushion plants and herbivory drive the water-holding capacity of the high Andean peatlands in Bolivia. EGU General Assembly Conference Abstracts: 7160.

Peer) reviewing PDF | (2020:10:54631:1:0:NEW 12 Mar 2021) 
660

661

662

663

664

665

666

667

668

669

670

671

672

673

674

675

676

677

678

679

680

681

682

683

684

685

686

687

688

689

690

691

692

Buytaert W, Cuesta-Camacho F, Tobón C. 2011. Potential impacts of climate change on the environmental services of humid tropical alpine regions: Climate change and environmental services. Global Ecology and Biogeography 20:19-33. DOI: 10.1111/j.1466-8238.2010.00585.x.

Brugger SO, Gobet E, van Leeuwen JF, Ledru M-P, Colombaroli D, van der Knaap WO, Lombardo U, Escobar-Torrez K, Finsinger W, Rodrígues L. 2016. Long-term man-environment interactions in the Bolivian Amazon: 8000 years of vegetation dynamics. Quaternary Science Reviews 132:114-128.

Cabrera M, Samboni-Guerrero V, Duivenvoorden JF. 2018. Non-destructive allometric estimates of above-ground and below-ground biomass of high-mountain vegetation in the Andes. Applied Vegetation Science 21:477-487. DOI: 10.1111/avsc.12381.

Cabrera M, Duivenvoorden JF. 2020. Drivers of aboveground biomass of high mountain vegetation in the Andes. Acta Oecologica 102:103504. DOI: 10.1016/j.actao.2019.103504.

Cárdenas MF, Tobón C. 2017.Recuperación del funcionamiento hidrológico de ecosistemas de páramo en Colombia. Revista UDCA Actualidad \& Divulgación Científica 20(2): 403-412.

Cárdenas MF, Tobón C, Rock BN, del Valle JI. 2018. Ecophysiology of frailejones (Espeletia spp.), and its contribution to the hydrological functioning of páramo ecosystems. Plant Ecology 219:185-198. DOI: $10.1007 / \mathrm{s} 11258-017-0787-\mathrm{x}$.

Castaño-Uribe C. 2002. Páramos y ecosistemas alto andinos de Colombia en condición Hotspot y Global Climatic Tensor. Bogotá: Instituto de Hidrología, Metereología y Estudios Ambientales.

Castellanos Camacho LI. 2011. Conocimiento etnobotánico, patrones de uso y manejo de plantas útiles en la cuenca del río Cane-Iguaque (Boyacá - Colombia): una aproximación desde los sistemas de uso de la biodiversidad. Ambiente \& Sociedade 14:45-75. DOI: 10.1590/S1414-753X2011000100004.

Chevallier P, Pouyaud B, Suarez W, Condom T. 2011. Climate change threats to environment in the tropical Andes: glaciers and water resources. Regional Environmental Change 11:179-187.

Clark JD, Dunn JE, Smith KG. 1993. A Multivariate Model of Female Black Bear Habitat Use for a

Geographic Information System. The Journal of Wildlife Management 57:519. DOI:

$10.2307 / 3809276$.

Collevatti RG, Terribile LC, de Oliveira G, Lima-Ribeiro MS, Nabout JC, Rangel TF, Diniz-Filho JAF. 2013. Drawbacks to palaeodistribution modelling: the case of South American seasonally dry forests. Journal of Biogeography 40:345-358.

Cook FE. 1995. Economic botany data collection standard. London: Royal Botanic Gardens (Kew). Cuesta-Camacho F, Peralvoco M, Ganzenmüller A. 2008. Posibles efectos del calentamiento global sobre el nicho climático de algunas especies en los Andes Tropicales. Páramo y Cambio Climático $23: 15-38$.

Peer) reviewing PDF | (2020:10:54631:1:0:NEW 12 Mar 2021) 
693

694

695

696

697

698

699

700

701

702

703

704

705

706

707

708

709

710

711

712

713

714

715

716

717

718

719

720

721

722

723

724

725

726

Cuesta F, Muriel P, Llambí LD, Halloy S, Aguirre N, Beck S, Carilla J, Meneses RI, Cuello S, Grau A, Gámez LE, Irazábal J, Jácome J, Jaramillo R, Ramírez L, Samaniego N, Suárez-Duque D, Thompson N, Tupayachi A, Viñas P, Yager K, Becerra MT, Pauli H, Gosling WD. 2017. Latitudinal and altitudinal patterns of plant community diversity on mountain summits across the tropical Andes. Ecography 40:1381-1394. DOI: 10.1111/ecog.02567.

Cuesta F, Llambí LD, Huggel C, Drenkhan F, Gosling WD, Muriel P, Jaramillo R, Tovar C. 2019. New land in the Neotropics: a review of biotic community, ecosystem, and landscape transformations in the face of climate and glacier change. Regional Environmental Change:1-20.

Demšar U, Harris P, Brunsdon C, Fotheringham AS, McLoone S. 2013. Principal Component Analysis on Spatial Data: An Overview. Annals of the Association of American Geographers 103:106-128. DOI: $10.1080 / 00045608.2012 .689236$.

Dettmers R, Buehler DA, Bartlett JB. 2002. A test and comparison of wildlife-habitat modeling techniques for predicting bird occurrence at a regional scale. In: Scott JM, Heglund PJ, Morrison ML, Haufler JB, Wall WA, Samson FB eds. Predicting species occurrences: issues of accuracy and scale. Washington: Island Press, 607-616.

Diaconis P, Efron B. 1983. Computer-intensive methods in statistics. Scientific American 248:116-130. Diazgranados M. 2012. A nomenclator for the frailejones (Espeletiinae Cuatrec., Asteraceae). Phytokeys 16:1-52. DOI: 10.3897/phytokeys.16.3186.

Diazgranados M, Allkin B, Black N, Cámara-Leret R, Canteiro C, Carretero J, Eastwood R, Hargreaves S, Hudson A, Milliken W, Nesbitt M, Ondo I, Patmore K, Pironon S, Turner R, Ulian T. 2020. World Checklist of Useful Plant Species. Produced by the Royal Botanic Gardens, Kew. Knowledge Network for Biocomplexity. DOI: 10.5063/F1CV4G34.

Diazgranados M, Allkin B, Ávila F, Baker W, Bishop D, Black N, Bystriakova N, Carretero J, Castellanos-Castro C, Cely M, Colville L, Cossu T, Davies L, Díaz A, dSouza J, García F, Gaya E, Graves E, Green L, Haigh A, Hammond DS, Hendigo P, Herrera A, Hillebrecht W, Howes M-J, Iggulden D, Kersey P, Kor L, Mattana E, Milliken W, Mira M, Moat J, Monro A, Morley J, Murphy V, Nesbitt M, Ondo I, Parker L, Phillips S, Piquer M, Pritchard HW, Reis P, Rojas T, Ruff J, Stone M, Tanimoto M, Torres G, Tovar C, Turner R, Taylor R, Utteridge T, Vargas N, Weech M-H, White K, Wilkin P, Williams J, Ulian T. 2020. ColPlantA: Colombian resources for Plants made Accessible (2nd ed.). Royal Botanic Gardens, Kew, Richmond, UK.

Dyer LA, Singer M, Lill J, Stireman J, Gentry G, Marquis RJ, Ricklefs RE, Greeney HF, Wagner DL, Morais H. 2007. Host specificity of Lepidoptera in tropical and temperate forests. Nature 448:696699.

Efron B. 1979. Bootstrap methods: another look at the jackknife. The Annals of Statistics 7:1-26.

Peer) reviewing PDF | (2020:10:54631:1:0:NEW 12 Mar 2021) 
727

728

729

730

731

732

733

734

735

736

737

738

739

740

741

742

743

744

745

746

747

748

749

750

751

752

753

754

755

756

757

758

759

760

Etherington TR. 2019. Mahalanobis distances and ecological niche modelling: correcting a chi-squared probability error. PeerJ 7:e6678. DOI: 10.7717/peerj.6678.

Etherington TR, Lieske DJ. 2019. [Re] Resampling methods for evaluating classification accuracy of wildlife habitat models. ReScience C 5:1, \#4. DOI: 10.5281/ZENODO.3234524.

Fadrique B, Báez S, Duque Á, Malizia A, Blundo C, Carilla J, Osinaga-Acosta O, Malizia L, Silman M, Farfán-Ríos W, Malhi Y, Young KR, Cuesta F, Homeier J, Peralvo M, Pinto E, Jadan O, Aguirre N, Aguirre Z, Feeley KJ. 2018. Widespread but heterogeneous responses of Andean forests to climate change. Nature 564:207-212. DOI: 10.1038/s41586-018-0715-9.

Fajardo Rojas AE. 2019. Variabilidad climática y disponibilidad hídrica en los valles de Ubaté, Chiquinquira y Alto Chicamocha, Colombia. Acta Agronómica 68:182-195. DOI: 10.15446/acag.v68n3.69082.

Farber O, Kadmon R. 2003. Assessment of alternative approaches for bioclimatic modeling with special emphasis on the Mahalanobis distance. Ecological Modelling 160:115-130. DOI: 10.1016/S03043800(02)00327-7.

Farley KA, Bremer LL. 2017. "Water Is Life”: Local Perceptions of Páramo Grasslands and Land Management Strategies Associated with Payment for Ecosystem Services. Annals of the American Association of Geographers 107:371-381. DOI: 10.1080/24694452.2016.1254020.

Feeley KJ, Silman MR. 2010. Land-use and climate change effects on population size and extinction risk of Andean plants. Global Change Biology 16:3215-3222. DOI: 10.1111/j.13652486.2010.02197.x.

Feeley KJ, Silman MR, Bush MB, Farfan W, Cabrera KG, Malhi Y, Meir P, Revilla NS, Quisiyupanqui MNR, Saatchi S. 2011. Upslope migration of Andean trees. Journal of Biogeography 38:783-791. DOI: $10.1111 /$ j.1365-2699.2010.02444.x.

Feng D, Tierney L. 2008. Computing and displaying isosurfaces in R. Journal of Statistical Software 28(1): 1-24.

Fitzpatrick MC, Blois JL, Williams JW, Nieto-Lugilde D, Maguire KC, Lorenz DJ. 2018. How will climate novelty influence ecological forecasts? Using the Quaternary to assess future reliability. Global Change Biology 24:3575-3586.

Flantua SG, Hooghiemstra H. 2018. Historical connectivity and mountain biodiversity. In: Hoorn C, Perrigo A, Antonelli A, eds. Mountains, climate and biodiversity, 171-185.

Flantua SGA, O'Dea A, Onstein RE, Giraldo C, Hooghiemstra H. 2019. The flickering connectivity system of the north Andean páramos. Journal of Biogeography 46:1808-1825. 10.1111/jbi.13607.

Flantua, SGA, Payne, D, Borregaard, MK, Beierkuhnlein, C, Steinbauer, MJ, Dullinger, S, Essl, F, Irl, SDH, Kienle, D, Kreft, H, Lenzner, B, Norder, SJ, Rijsdijk, KR, Rumpf, SB, Weigelt, P, Field, R..

Peer) reviewing PDF | (2020:10:54631:1:0:NEW 12 Mar 2021) 
761

762

763

764

765

766

767

768

769

770

771

772

773

774

775

776

777

778

779

780

781

782

783

784

785

786

787

788

789

790

791

792

793

794

2020. Snapshot isolation and isolation history challenge the analogy between mountains and islands used to understand endemism. Global Ecology and Biogeography 29: 1651-1673.

Galvis M. 2014. Etnobotánica y usos de las plantas de la comunidad rural del municipio de Cerinza, Boyacá, Colombia. Prospectiva Científica 10: 38-54.

Givnish TJ, Barfuss MHJ, Van Ee B, Riina R, Schulte K, Horres R, Gonsiska PA, Jabaily RS, Crayn DM, Smith JAC, Winter K, Brown GK, Evans TM, Holst BK, Luther H, Till W, Zizka G, Berry PE, Sytsma KJ. 2011. Phylogeny, adaptive radiation, and historical biogeography in Bromeliaceae:

$$
\text { Insights from an eight-locus plastid phylogeny. American Journal of Botany 98:872-895. DOI: }
$$
10.3732/ajb.1000059.

Gómez-Ruiz PA, Lindig-Cisneros R, Vargas-Ríos O. 2013. Facilitation among plants: A strategy for the ecological restoration of the high-andean forest (Bogotá, DC-Colombia). Ecological Engineering $57: 267-275$.

Gutiérrez-Bonilla FdP, Baptiste MP, García LM, Cárdenas J, Salgado-Negret B, Vásquez Valderrama M, Castellanos-Castro C, González R, Aguilar-Garavito M, Castaño N. 2017. Plantas exóticas con alto potencial de invasión en Colombia. Humboldt Institute, Colombia. 295 p. ISBN 978-958-541809-7.

Hijmans RJ, Cameron SE, Parra JL, Jones PG, Jarvis A. 2005. Very high resolution interpolated climate surfaces for global land areas. International Journal of Climatology 25:1965-1978. DOI: $10.1002 /$ joc. 1276.

Hijmans RJ. 2018. raster: Geographic Data Analysis and Modeling. R package version 2.8-4. Available at https://CRAN.R-project.org/package=raster (accessed 06 July 2020).

Hisano M, Searle EB, Chen HYH. 2018. Biodiversity as a solution to mitigate climate change impacts on the functioning of forest ecosystems: Biodiversity to mitigate climate change impacts. Biological Reviews 93:439-456. DOI: 10.1111/brv.12351.

Hornung-Leoni CT, Sosa V. 2008. Morphological phylogenetics of Puya subgenus Puya (Bromeliaceae). Botanical Journal of the Linnean Society 156:93-110. DOI: 10.1111/j.10958339.2007.00740.x.

Hotelling H. 1933a. Analysis of a complex of statistical variables into principal components. Journal of Educational Psychology 24(6):417-441. DOI: 10.1037/h0071325.

Hotelling H. 1933b. Analysis of a complex of statistical variables into principal components. Journal of Educational Psychology 24(7):498-520. DOI: 10.1037/h0070888.

Hribljan JA, Suárez E, Heckman KA, Lilleskov EA, Chimner RA. 2016. Peatland carbon stocks and accumulation rates in the Ecuadorian páramo. Wetlands Ecology and Management 24:113-127. DOI: $10.1007 / \mathrm{s} 11273-016-9482-2$. 
795

796

797

798

799

800

801

802

803

804

805

806

807

808

809

810

811

812

813

814

815

816

817

818

819

820

821

822

823

824

825

826

827

Hutchinson GE. 1957. Concluding Remarks. Cold Spring Harbor Symposia on Quantitative Biology 22:415-427. DOI: 10.1101/SQB.1957.022.01.039.

IDEAM. 2012. Glaciares de Colombia, más que montañas con hielo. Bogotá: Comité de Comunicaciones y Publicaciones del IDEAM.

Instituto de Investigación de Recursos Biológicos Alexander von Humbodlt. 2014. Plantas alimenticias y medicinales nativas de Colombia. 2567 registros, aportados por: Castellanos, C. (Contacto del recurso), Valderrama, N. (Creador del recurso, Autor), Bernal, Y. (Autor), García, N. (Autor). http://i2d.humboldt.org.co/ceiba/resource.do?r=1s_colombia_magnoliophyta_2014.

Jackson ST, Overpeck JT. 2000. Responses of plant populations and communities to environmental changes of the late Quaternary. Paleobiology 26:194-220. DOI: 10.1666/00948373(2000)26[194:ROPPAC]2.0.CO;2.

James FC. 1971. Ordinations of habitat relationships among breeding birds. The Wilson Bulletin 83: $215-236$.

Jarvis A, Reuter HI, Nelson A, Guevara E. 2008. Hole-filled SRTM for the globe Version 4. The CGIAR-CSI SRTM 90m Database. Available at http://srtm.csi.cgiar.org (accessed 06 July 2020).

Jiménez-Rivillas C, García JJ, Quijano-Abril MA, Daza JM, Morrone JJ. 2018. A new biogeographical regionalisation of the Páramo biogeographic province. Australian Systematic Botany 31:296. $10.1071 / \mathrm{sb} 18008$.

Johnson CJ, Gillingham MP. 2005. An evaluation of mapped species distribution models used for conservation planning. Environmental Conservation 32:117-128.

Josse C, Cuesta F, Navarro G, Barrena V, Chacón-Moreno E, Ferreira W, Peralvo M, Saito J, Tovar A. 2009. Mapa de ecosistemas de los Andes del Norte y Centro, Bolivia, Colombia, Ecuador, Perú, Venezuela. Secretaría General de la Comunidad Andina, Programa Regional ECOBONA, CONDESAN-Proyecto Páramo Andino, Programa BioAndes, EcoCiencia, NatureServe, LTAUNALM, IAvH, ICAE-ULA, CDC-UNALM, RUMBOL SRL, Lima. Available at http://www.saber.ula.ve/handle/123456789/39336 (accessed 06 July 2020).

Kampstra P. 2008. Beanplot: a boxplot alternative for visual comparison of distributions. Journal of Statistical Software 28:1-9.

Lagos-López MI. 2007. Estudio etnobotánico de especies vegetales con propiedades medicinales en seis municipios de Boyacá, Colombia. Actualidades Biológicas 29:87-96.

Larsen TH, Brehm G, Navarrete H, Franco P, Gomez H, Mena JL, Morales V, Argollo J, Blacutt L, Canhos V. 2011. Range shifts and extinctions driven by climate change in the tropical Andes: synthesis and directions. Climate change and biodiversity in the tropical Andes:47-67.

Peer] reviewing PDF | (2020:10:54631:1:0:NEW 12 Mar 2021) 
828

829

830

831

832

833

834

835

836

837

838

839

840

841

842

843

844

845

846

847

848

849

850

851

852

853

854

855

856

857

858

859

860

Laverde Martínez C. 2008. Servicios ecosistémicos que provee el páramo de la cuenca alta del río Teusacá: Percepción de los actores campesinos y su relación con los planes ambientales en la vereda Verjón Alto, Bogotá D.C. Thesis for the title of Ecologist. Pontificia Universidad Javeriana.

Lembrechts JJ, Nijs I, Lenoir J. 2019. Incorporating microclimate into species distribution models. Ecography 42: 1267-1279. DOI: 10.1111/ecog.03947

León O, Jiménez D, Marín C. 2015. Marco conceptual para la identificación de la zona de transición entre bosque altoandino y páramo. Transición bosque-páramo Bases conceptuales y métodos para su identificación en los Andes colombianos:13-63.

Llambí LD, Becerra MT, Peralvo M, Avella A, Baruffol M, Díaz LJ. 2020. Monitoring Biodiversity and Ecosystem Services in Colombia's High Andean Ecosystems: Toward an Integrated Strategy. Mountain Research and Development 39. DOI: 10.1659/MRD-JOURNAL-D-19-00020.1.

Londoño C, Cleef A, Madriñán S. 2014. Angiosperm flora and biogeography of the páramo region of Colombia, Northern Andes. Flora - Morphology, Distribution, Functional Ecology of Plants 209:8187. 10.1016/j.flora.2013.11.006.

Luteyn JL. 1999. Páramos: a checklist of plant diversity, geographical distribution, and botanical literature. New York: The New York Botanical Garden Press.

Lutz DA, Powell RL, Silman MR. 2013. Four Decades of Andean Timberline Migration and Implications for Biodiversity Loss with Climate Change. PLoS ONE 8:e74496. DOI: 10.1371/journal.pone.0074496.

Maguire KC, Nieto-Lugilde D, Fitzpatrick MC, Williams JW, Blois JL. 2015. Modeling species and community responses to past, present, and future episodes of climatic and ecological change. Annual Review of Ecology, Evolution, and Systematics 46.

Mahalanobis PC. 1936. On the generalised distance in statistics. Proceedings of the National Institute of Sciences of India 2:49-55.

Malcolm JR, Liu C, Neilson RP, Hansen L, Hannah L. 2006. Global Warming and Extinctions of Endemic Species from Biodiversity Hotspots. Conservation Biology 20:538-548. DOI: 10.1111/j.1523-1739.2006.00364.x.

Maldonado VGM. 2017. Ecohydrology of the Andes Páramo Region. London: CRC Press.

Males J. 2016. Think tank: water relations of Bromeliaceae in their evolutionary context. Botanical Journal of the Linnean Society 181:415-440. DOI: 10.1111/boj.12423.

Maslin M. 2014. Climate Change: a very short introduction. Oxford: Oxford University Press. Mavárez J, Bézy S, Goeury T, Fernández A, Aubert S. 2018. Current and future distributions of Espeletiinae (Asteraceae) in the Venezuelan Andes based on statistical downscaling of climatic 
861

862

863

864

865

866

867

868

869

870

871

872

873

874

875

876

877

878

879

880

881

882

883

884

885

886

887

888

889

890

891

892

893

variables and niche modelling. Plant Ecology \& Diversity:1-15. DOI:

10.1080/17550874.2018.1549599.

McKinney W. 2013. Python for Data Analysis. Sebastopol: O'Reilly Media, Inc.

McMichael CNH. 2020. Ecological legacies of past human activities in Amazonian forests. New Phytol. DOI: $10.1111 / \mathrm{nph} .16888$.

Medina MM, Varela A, Martínez C. 2010. Registro de daño a los frailejones (Asteraceae: Espeletia spp.) por insectos y hongos patógenos en el PNN Chingaza (Colombia). Cespedesia 32:67-70.

Moor H, Hylander K, Norberg J. 2015. Predicting climate change effects on wetland ecosystem services using species distribution modeling and plant functional traits. AMBIO 44:113-126. DOI:

$$
\text { 10.1007/s13280-014-0593-9. }
$$

Mora MA, Llambí LD, Ramírez L. 2019. Giant stem rosettes have strong facilitation effects on alpine plant communities in the tropical Andes. Plant Ecology \& Diversity 12:593-606. DOI: 10.1080/17550874.2018.1507055.

Morelli F, Tryjanowski P. 2016. The dark side of the "redundancy hypothesis" and ecosystem assessment. Ecological Complexity 28:222-229. DOI: 10.1016/j.ecocom.2016.07.005.

Moret P, Muriel P, Jaramillo R, Dangles O. 2019. Humboldt's Tableau Physique revisited. Proceedings of the National Academy of Sciences 116:12889-12894. DOI: 10.1073/pnas.1904585116.

Morueta-Holme N, Engemann K, Sandoval-Acuña P, Jonas JD, Segnitz RM, Svenning J-C. 2015.

Strong upslope shifts in Chimborazo's vegetation over two centuries since Humboldt. Proceedings of the National Academy of Sciences 112:12741-12745. DOI: 10.1073/pnas.1509938112.

Neuwirth E. 2014. RColorBrewer: ColorBrewer Palettes. R package version 1.1-2. Available at https://CRAN.R-project.org/package=RColorBrewer (accessed 06 July 2020).

Nieto M, Cardona LF, Agudelo C. 2015. Servicios ecosistémicos, provisión y regulación hídrica en los páramos. In: Ungar, P. ed. Hojas de ruta. Guías para el estudio socioecológico de la alta montaña en Colombia. Bogotá: Instituto de Investigación de Recursos Biológicos Alexander von Humboldt.

Nguyen LH, Holmes S. 2019. Ten quick tips for effective dimensionality reduction. PLOS Computational Biology 15:e1006907. DOI: 10.1371/journal.pcbi.1006907.

Nogués-Bravo D. 2009. Predicting the past distribution of species climatic niches. Global Ecology and Biogeography 18:521-531. 10.1111/j.1466-8238.2009.00476.x.

Nychka D, Furrer R, Paige J, Sain S. 2017. fields: Tools for spatial data. R package version 9.6.

Available at: https://cran.r-project.org/web/packages/fields/index.html (accessed 06 July 2020).

Ordonez A, Williams JW. 2013. Climatic and biotic velocities for woody taxa distributions over the last 16000 years in eastern North America. Ecology Letters 16:773-781. 
894

895

896

897

898

899

900

901

902

903

904

905

906

907

908

909

910

911

912

913

914

915

916

917

918

919

920

921

922

923

924

925

926

927

Pearson K.1901. On lines and planes of closest fit to systems of points in space. The London, Edinburgh, and Dublin Philosophical Magazine and Journal of Science 2(11): 559-572.

Pelayo RC, Soriano PJ, Márquez NJ, Navarro L. 2019. Phenological patterns and pollination network structure in a Venezuelan páramo: a community-scale perspective on plant-animal interactions. Plant Ecology \& Diversity 12:607-618. DOI: 10.1080/17550874.2019.1675096.

Pérez-Escobar OA, Cámara-Leret R, Antonelli A, Bateman R, Bellot S, Chomicki G, Cleef A, Diazgranados M, Dodsworth S, Jaramillo C, Madriñan S, Olivares I, Zuluaga A, Bernal R. 2018. Mining threatens Colombian ecosystems. Science 359: 1475. DOI: 10.1126/science.aat4849.

Pérez-Niño WF, Leguizamón-Arias WY. 2020. Gobernanza ambiental en Boyacá: un análisis «glocal». Entramado 16:202-218. https://doi.org/10.18041/1900-3803/entramado.2.6662.

Pérez F, Granger BE, Hunter JD. 2011. Python: An Ecosystem for Scientific Computing. Computing in Science \& Engineering 13:13-21. DOI: 10.1109/MCSE.2010.119.

R Core Team. 2018. R: A language and environment for statistical computing. R Foundation for Statistical Computing, Vienna, Austria. Available at https://www.R-project.org/ (accessed 06 July 2020).

Rada F, Azócar A, García-Núñez C. 2019. Plant functional diversity in tropical Andean páramos. Plant Ecology \& Diversity 12:539-553. DOI: 10.1080/17550874.2019.1674396.

Rangel-Ch O. 2000. Diversidad biótica III: La región de vida paramuna. Bogotá: Universidad Nacional de Colombia, Facultad de Ciencias, Instituto de Ciencias Naturales \& Instituto de investigación de recursos biológicos Alexander von Humboldt.

Ramirez-Villegas J, Cuesta F, Devenish C, Peralvo M, Jarvis A, Arnillas CA. 2014. Using species distributions models for designing conservation strategies of Tropical Andean biodiversity under climate change. Journal for Nature Conservation 22:391-404. DOI: 10.1016/j.jnc.2014.03.007.

Rodríguez-Morales M, Acevedo D, Buytaert W, Ablan N, De Bièvre B. 2014. El páramo andino como productor y regulador del recurso agua. In: Cuesta F, Sevink J, Llambí LD, De Bièvre B, Posner J, eds. Avances en investigación para la conservación de los páramos andinos. Lima, Quito: CONDESAN, 245-265.

Rodríguez-Morales M, Acevedo-Novoa D, Machado D, Ablan M, Dugarte W, Dávila F. 2019. Ecohydrology of the Venezuelan páramo: water balance of a high Andean watershed. Plant Ecology \& Diversity 12:573-591. DOI: 10.1080/17550874.2019.1673494.

Rosenfeld JS. 2002a. Functional redundancy in ecology and conservation. Oikos 98:156-162. DOI: 10.1034/j.1600-0706.2002.980116.x.

Rosenfeld JS. 2002b. Logical fallacies in the assessment of functional redundancy. Conservation Biology 16(3): 837-839.

Peer) reviewing PDF | (2020:10:54631:1:0:NEW 12 Mar 2021) 
928

929

930

931

932

933

934

935

936

937

938

939

940

941

942

943

944

945

946

947

948

949

950

951

952

953

954

955

956

957

958

959

960

961

Sandoval D, Rada F, Sarmiento L. 2019. Stomatal response functions to environmental stress of dominant species in the tropical Andean páramo. Plant Ecology \& Diversity 12:649-661. DOI: 10.1080/17550874.2019.1683094.

Sevink J, Tonneijck F, Kalbitz K, Cammeraat L. 2014. Dinámica del carbono en los ecosistemas de páramo de los Andes neotropicales: revisión de literatura sobre modelos y parámetros relevantes. In: Cuesta F, Sevink J, Llambí LD, De Bièvre B, Posner J, eds. Avances en investigación para la conservación de los páramos andinos. Lima, Quito: CONDESAN, 549-579.

Sheldon KS, Yang S, Tewksbury JJ. 2011. Climate change and community disassembly: impacts of warming on tropical and temperate montane community structure: Climate change and community disassembly. Ecology Letters 14:1191-1200. DOI: 10.1111/j.1461-0248.2011.01689.x.

Sklenář P, Hedberg I, Cleef AM. 2014. Island biogeography of tropical alpine floras. Journal of Biogeography 41(2): 287-297. DOI:10.1111/jbi.12212.

Soberon J, Nakamura M. 2009. Niches and distributional areas: Concepts, methods, and assumptions. Proceedings of the National Academy of Sciences 106:19644-19650. DOI: 10.1073/pnas.0901637106.

Sylvester SP, Soreng RJ, Bravo-Pedraza WJ, Cuta-Alarcon LE, Giraldo-Cañas D, Aguilar-Cano J, Peterson PM. 2019. Páramo Calamagrostis s.l. (Poaceae): An updated list and key to the species known or likely to occur in páramos of NW South America and southern Central America including two new species, one new variety and five new records for Colombia. PhytoKeys 122:29-78. DOI: 10.3897/phytokeys.122.33032.

Tapasco J, Martínez J, Calderón S, Romero G, Ordóñez DA, Álvarez A, Sanchez-Aragon L, Ludeña CE. 2015. Impactos económicos del cambio climático en Colombia: Sector ganadero. Washington DC: Banco Interamericano de Desarrollo/Departamento Nacional de Planeación.

https://publications.iadb.org/publications/spanish/document/Impactos-econ\%C3\%B3micos-delcambio-clim\%C3\%A1tico-en-Colombia-sector-ganadero.pdf.

de la Torre L, Navarrete H, Muriel P, Macia MJ, Balslev H. 2008. Enciclopedia de las plantas útiles del Ecuador. Quito, Aarhus. Herbario QCA de la Escuela de Ciencias Biológicas de la Pontificia Universidad Católica del Ecuador \& Herbario AAU del Departamento de Ciencias Biológicas de la Universidad de Aarhus.

Tovar C, Seijmonsbergen AC, Duivenvoorden JF. 2013a. Monitoring land use and land cover change in mountain regions: An example in the Jalca grasslands of the Peruvian Andes. Landscape and Urban Planning 112:40-49. DOI: 10.1016/j.landurbplan.2012.12.003.

Tovar C, Arnillas CA, Cuesta F, Buytaert W. 2013b. Diverging Responses of Tropical Andean Biomes under Future Climate Conditions. PLoS ONE 8:e63634. DOI: 10.1371/journal.pone.0063634.

Peer) reviewing PDF | (2020:10:54631:1:0:NEW 12 Mar 2021) 
962

963

964

965

966

967

968

969

970

971

972

973

974

975

976

977

978

979

980

981

982

983

984

985

986

987

988

989

990

991

992

993

994

995

Tovar C, Melcher I, Kusumoto B, Cuesta F, Cleef A, Meneses RI, Halloy S, Llambí LD, Beck S, Muriel P, Jaramillo R, Jácome J, Carilla J. 2020. Plant dispersal strategies of high tropical alpine communities across the Andes. Journal of Ecology 1-13. DOI: 10.1111/1365-2745.13416.

Tsoar A, Allouche O, Steinitz O, Rotem D, Kadmon R. 2007. A comparative evaluation of presenceonly methods for modelling species distribution. Diversity and Distributions 13:397-405. DOI: 10.1111/j.1472-4642.2007.00346.x.

UICN. 2015. Comunidades de los páramos. Available at https://www.portalces.org/paramos (accessed 06 July 2020).

Urgiles N, Cofre D, Loján P, Maita J, Báez S. 2018. Diversidad de plantas, estructura de la comunidad y biomasa aérea en un páramo del sur del Ecuador. Bosques Latitud Cero 8:44-56.

Valencia JB, Mesa J, León JG, Madriñán S, Cortés AJ. 2020. Climate Vulnerability Assessment of the Espeletia Complex on Páramo Sky Islands in the Northern Andes. Frontiers in Ecology and Evolution 8. DOI: 10.3389/fevo.2020.565708.

Varela S, Lobo JM, Hortal J. 2011. Using species distribution models in palaeobiogeography: A matter of data, predictors and concepts. Palaeogeography, Palaeoclimatology, Palaeoecology 310:451-463. DOI: 10.1016/j.palaeo.2011.07.021.

Verbyla DL, Litvaitis JA. 1989. Resampling methods for evaluating classification accuracy of wildlife habitat models. Environmental Management 13:783-787.

Walker PA, Cocks KD. 1991. HABITAT: A Procedure for Modelling a Disjoint Environmental Envelope for a Plant or Animal Species. Global Ecology and Biogeography Letters 1:108. DOI: $10.2307 / 2997706$.

Warmerdam F. 2008. The Geospatial Data Abstraction Library. In: Hall GB, Leahy MG eds. Open Source Approaches in Spatial Data Handling. Advances in Geographic Information Science. Berlin, Heidelberg: Springer Berlin Heidelberg, 87-104. DOI: 10.1007/978-3-540-74831-1_5.

van der Walt S, Colbert SC, Varoquaux G. 2011. The NumPy Array: A Structure for Efficient Numerical Computation. Computing in Science \& Engineering 13:22-30. DOI:

10.1109/MCSE.2011.37.

Yachi S, Loreau M. 1999. Biodiversity and ecosystem productivity in a fluctuating environment: The insurance hypothesis. Proceedings of the National Academy of Sciences 96:1463-1468. DOI: 10.1073/pnas.96.4.1463.

Young BE, Young K, Josse C. 2011. Vulnerability of Tropical Andean Ecosystems to Climate Change. In: Herzog SK, Martínez R, Jørgensen PM, Tiessen H, eds. Climate Change and Biodiversity in the Tropical Andes. São José dos Campos: Inter-American Institute for Global Change Research and Scientific Committee on Problems of the Environment,170-181.

Peer) reviewing PDF | (2020:10:54631:1:0:NEW 12 Mar 2021) 
996 Young KR, Ponette-González AG, Polk MH, Lipton JK. 2017. Snowlines and Treelines in the Tropical

997

998

999

1000

1001

1002

1003

1004

1005

1006

1007

1008

1009

1010

1011

1012

1013

1014

1015

1016

1017

1018

1019

Andes. Annals of the American Association of Geographers 107:429-440. DOI:

$$
\text { 10.1080/24694452.2016.1235479. }
$$

Valencia JB, Mesa J, León JG, Madriñán S, Cortés AJ. 2020. Climate Vulnerability Assessment of the Espeletia Complex on Páramo Sky Islands in the Northern Andes. Frontiers in Ecology and Evolution 8. DOI: 10.3389/fevo.2020.565708.

Vuille M, Francou B, Wagnon P, Juen I, Kaser G, Mark BG, Bradley RS. 2008. Climate change and tropical Andean glaciers: Past, present and future. Earth-Science Reviews 89:79-96. DOI:

$$
\text { 10.1016/j.earscirev.2008.04.002. }
$$

Vuille M, Carey M, Huggel C, Buytaert W, Rabatel A, Jacobsen D, Soruco A, Villacis M, Yarleque C, Elison Timm O, Condom T, Salzmann N, Sicart J-E. 2018. Rapid decline of snow and ice in the tropical Andes - Impacts, uncertainties and challenges ahead. Earth-Science Reviews 176:195-213. DOI: 10.1016/j.earscirev.2017.09.019.

Zhang C, Atkinson PM, George C, Wen Z, Diazgranados M, Gerard F. 2020. Identifying and mapping individual plants in a highly diverse high-elevation ecosystem using UAV imagery and deep learning. ISPRS Journal of Photogrammetry and Remote Sensing 169:280-291.

Zimmer A, Meneses RI, Rabatel A, Soruco A, Anthelme F. 2014. Characterizing the upward migration of high-Andean plant communities under the effects of global warming with early post-glacial chronosequences. Ecología en Bolivia 49:27-41.

Zimmer A, Meneses RI, Rabatel A, Soruco A, Dangles O, Anthelme F. 2018. Time lag between glacial retreat and upward migration alters tropical alpine communities. Perspectives in Plant Ecology, Evolution and Systematics 30:89-102. DOI: 10.1016/j.ppees.2017.05.003.

Zotz G, Leja M, Aguilar-Cruz Y, Einzmann HJR. 2020. How much water is in the tank? An allometric analysis with 205 bromeliad species. Flora 264:151557. DOI: 10.1016/j.flora.2020.151557.

Peer) reviewing PDF | (2020:10:54631:1:0:NEW 12 Mar 2021) 


\section{Table $\mathbf{1}$ (on next page)}

Richness of plants and lichens reported for Boyacá and its páramos.

Information extracted from the Colombian Catalogue of Plants and Lichens (Bernal, Gradstein $\&$ Celis, 2019). 
1 Table 1 - Richness of plants and lichens reported for Boyacá and its páramos. Information

2 extracted from the Colombian Catalogue of Plants and Lichens (Bernal, Gradstein \& Celis,

3 2019).

\begin{tabular}{|c|c|c|c|c|c|c|c|c|}
\hline Plant groups & $\begin{array}{l}\text { Bryo- } \\
\text { phyta }\end{array}$ & $\begin{array}{l}\text { Conife- } \\
\text { ropsida }\end{array}$ & $\begin{array}{c}\text { Cyca- } \\
\text { dopsida }\end{array}$ & Lichenes & $\begin{array}{l}\text { Magno- } \\
\text { liopsida }\end{array}$ & $\begin{array}{c}\text { Marchan- } \\
\text { tiophyta }\end{array}$ & $\begin{array}{c}\text { Pterido- } \\
\text { phyta }\end{array}$ & $\begin{array}{c}\text { Grand } \\
\text { Total }\end{array}$ \\
\hline & \multicolumn{8}{|c|}{ Boyacá (all the ecosystems) } \\
\hline Families & 46 & 2 & 1 & 37 & 183 & 30 & 34 & 333 \\
\hline Genera & 129 & 3 & 1 & 77 & 1191 & 85 & 107 & 1593 \\
\hline \multirow[t]{2}{*}{ Species } & 293 & 3 & 1 & 263 & 3369 & 247 & 470 & 4646 \\
\hline & \multicolumn{8}{|c|}{ Páramos of Boyacá (> 3,000 $\mathrm{m}$ a.s.l.) } \\
\hline Families & 41 & 2 & 0 & 29 & 117 & 30 & 24 & 243 \\
\hline Genera & 107 & 3 & 0 & 53 & 507 & 68 & 68 & 806 \\
\hline Species & 246 & 3 & 0 & 180 & 1500 & 180 & 245 & 2354 \\
\hline Native species & 246 & 2 & N/A & 180 & 1390 & 180 & 245 & 2243 \\
\hline
\end{tabular}

4 
Table 2 (on next page)

Examples of species that provide water regulation and materials. 
1 Table 2 - Examples of species that provide water regulation and materials

2

\begin{tabular}{|l|l|}
\hline $\begin{array}{l}\text { Ecosystem } \\
\text { service } \\
\text { provided }\end{array}$ & Species \\
\hline $\begin{array}{l}\text { Water } \\
\text { regulation }\end{array}$ & $\begin{array}{l}\text { Baccharis bogotensis Kunth, Calamagrostis effusa (Kunth)Steud., Carex pichinchensis Kunth, } \\
\text { Clethra fimbriata Kunth, Escallonia myrtilloides L.f., Escallonia paniculata (Ruiz \& Pav.) Schult., } \\
\text { Hesperomeles goudotiana (Decne.) Killip, Hypericum juniperinum Kunth, Morella parvifolia } \\
\text { (Benth.) Parra-Os., Nertera granadensis (Mutis ex L.f.) Druce, Paepalanthus dendroides (Kunth) } \\
\text { Kunth, Puya goudotiana Mez, Vaccinium meridionale Sw., Vallea stipularis L.f., Weinmannia } \\
\text { tomentosa L.f. }\end{array}$ \\
\hline Materials & $\begin{array}{l}\text { Baccharis bogotensis Kunth, Baccharis latifolia Pers., Baccharis macrantha Kunth, Baccharis } \\
\text { tricuneata Pers., Bejaria resinosa Mutis ex L.f., Bucquetia glutinosa DC, Calamagrostis effuse } \\
\text { (Kunth)Steud., Cavendishia bracteata (Ruiz \& Pav. ex J.St.-Hil.) Hoerold, Cestrum buxifolium } \\
\text { Kunth, Chusquea tessellate Munro, Clethra fimbriata Kunth, Diplostephium rosmarinifolium } \\
\text { Benth., Dodonaea viscosa Jacq., Drimys granadensis L.f., Duranta mutisii L.f., Escallonia } \\
\text { paniculata (Ruiz \& Pav.) Schult., Espeletia incana Cuatrec., Excremis coarctata (Ruiz \& Pav.) } \\
\text { Baker, Gaiadendron punctatum } \text { (Ruiz \& Pav.) G.Don, Galium hypocarpium (L.) Endl. ex Griseb., } \\
\text { Hesperomeles goudotiana (Decne.) Killip, Hypericum juniperinum Kunth, Jamesonia bogotensis } \\
\text { H.Karst., Juncus effusus L., Macleania rupestris (Kunth) A.C.Sm., Miconia squamulosa Triana, } \\
\text { Monnina salicifolia Ruiz \& Pav., Morella parvifolia (Benth.) Parra-Os., Mutisia orbignyana } \\
\text { Wedd., Myrsine coriacea (Sw.) R.Br. ex Roem. \& Schult., Orthrosanthus chimboracensis (Kunth) } \\
\text { Baker, Polylepis quadrijuga Bitter, Vaccinium floribundum Kunth, Vaccinium meridionale Sw., } \\
\text { Vallea stipularis L.f., Viburnum tinoides L.f., Weinmannia tomentosa L.f. }\end{array}$ \\
\hline
\end{tabular}


Figure 1

The department of Boyacá (Colombia), the study area and the main páramos.

PNN: National Nature Parks ('Parques Nacionales Naturales') of Colombia.
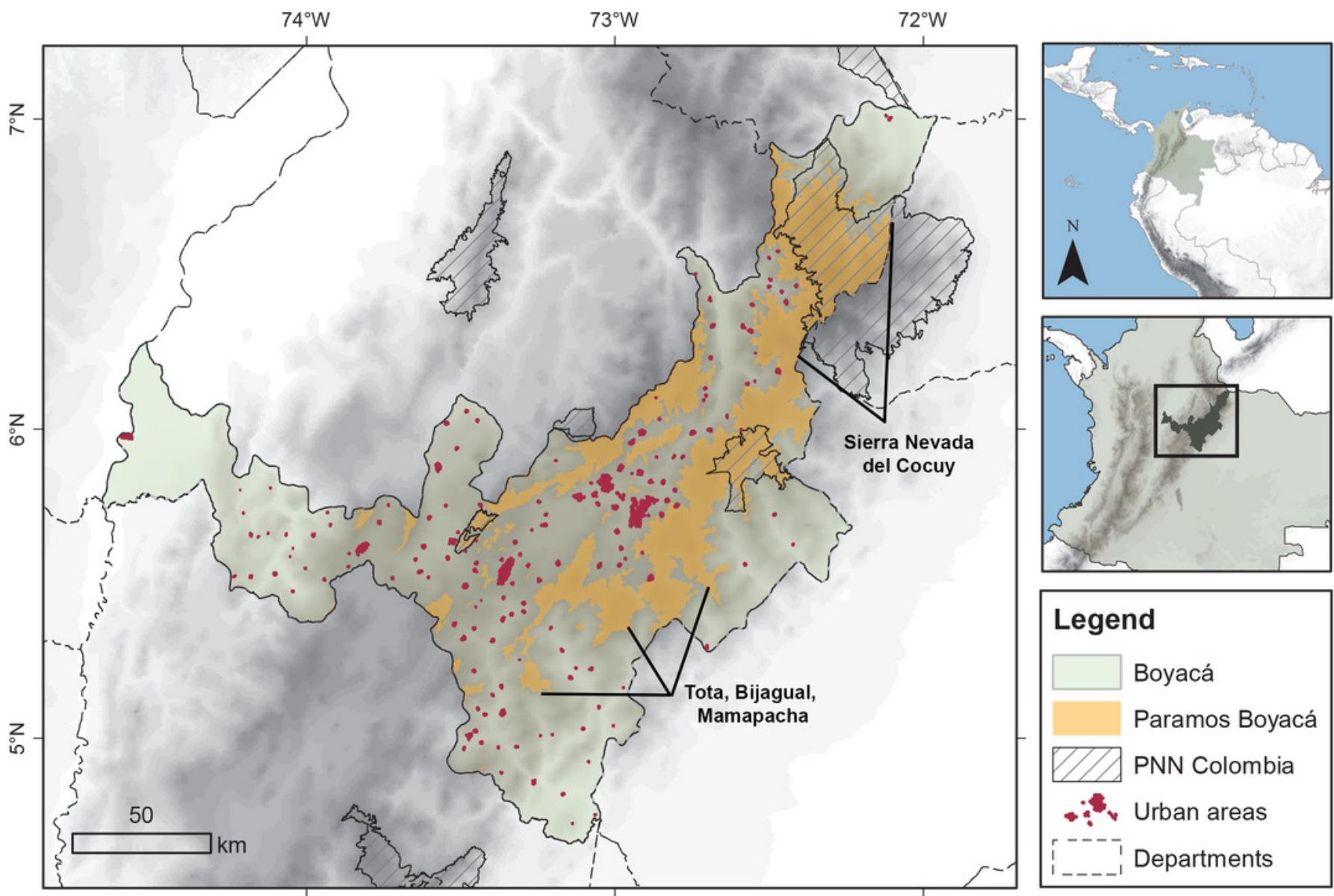

\section{Legend}

Boyacá

Paramos Boyacá

D/ PNN Colombia

$\because$ : Urban areas Departments 
Figure 2

Schematic overview of the project workflow.

The analysis required careful integration of plant uses recorded in the literature, plant occurrence data, and current and future climate data to produce estimates of how ecosystem services may change as a result of climate change.

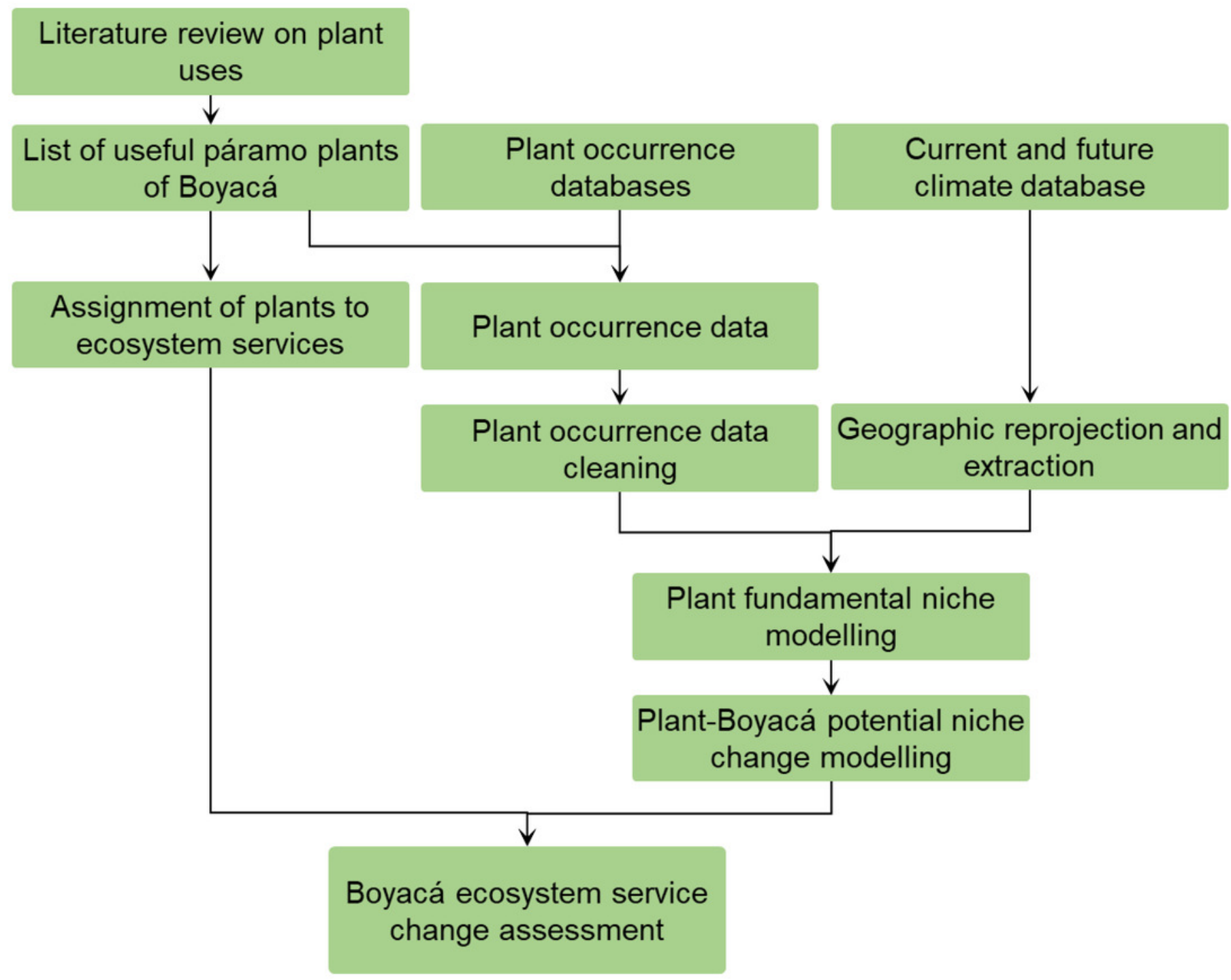




\section{Figure 3}

Example of Mahalanobis distance based fundamental niche modelling for bootstrap resamples 1, 2, and 1,000 of Espeletia boyacensis Cuatrec.

The bootstrap resample is shown by dots for which the size is indicative of the number of replicates in the sample. The probability of being within the fundamental niche is calculated from Mahalanobis distances for each sample and shown as ellipsoids at the $p>=0.9$ (smallest ellipsoid), $p>=0.5$, and $p>=0.1$ (largest ellipsoid) thresholds for bootstrap resamples (a) 1 , (b) 2 , and (c) 1000. For an animated version of this figure please see Supplementary Figure S1.

(a)

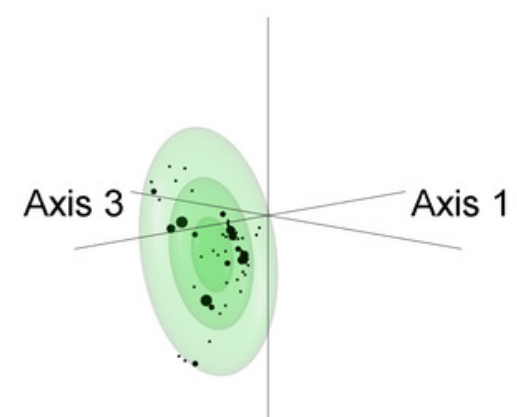

Axis 2 (b)

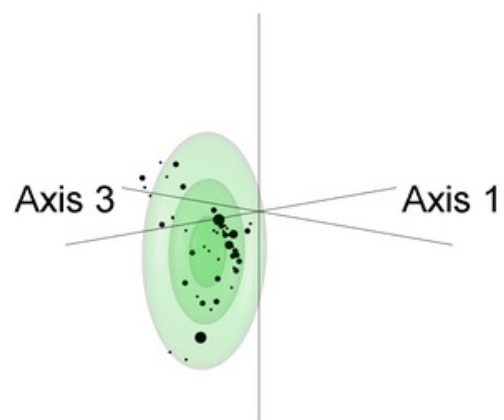

Axis 2 (c)

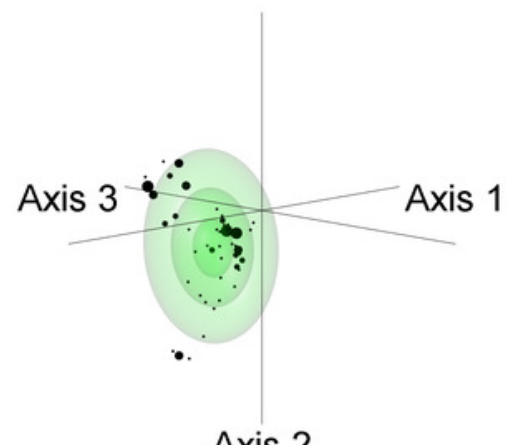

Axis 2 
Figure 4

Example potential niches for bootstrap resamples 1, 2, and 1,000 of Espeletia boyacensis Cuatrec.

Each subplot maps the potential niche probability for each bootstrap resample for (a) the present day, (b) 2050 under relative concentration pathway (RCP) 2.6, (c) 2070 under RCP 2.6, (d) 2050 under RCP 4.5, (e) 2070 under RCP 4.5, (f) 2050 under RCP 6.0, (g) 2070 under RCP 6.0, (h) 2050 under RCP 8.5, and (i) 2070 under RCP 8.5. 
(a) Present day
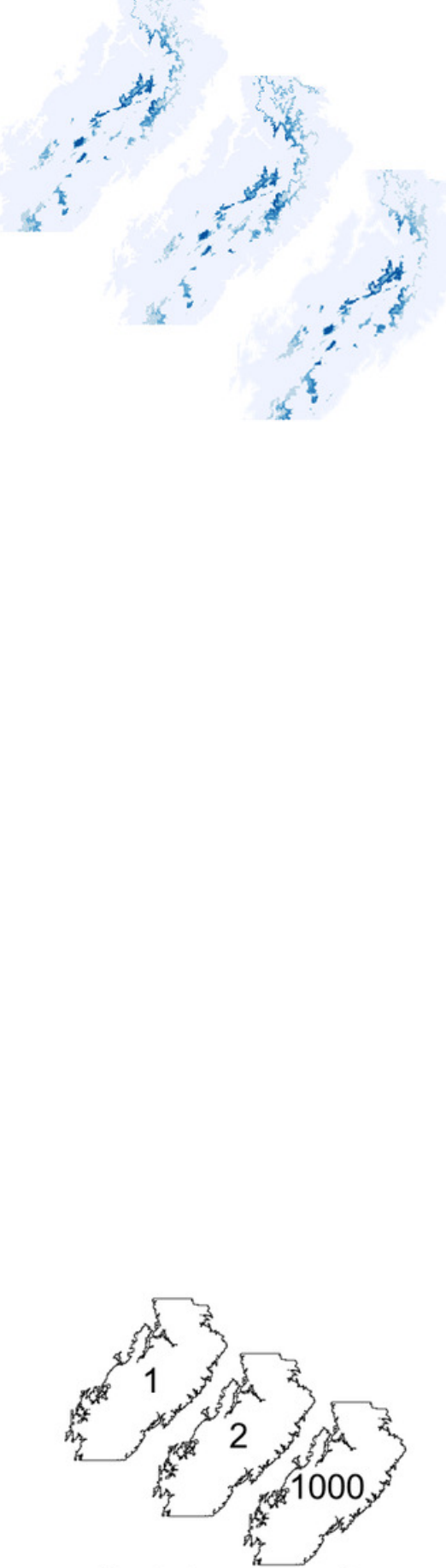

Bootstrap sample

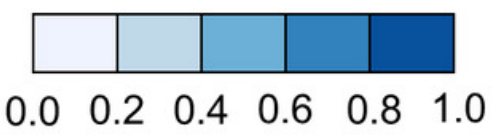

Potential niche probability (d) 2050 RCP 4.5
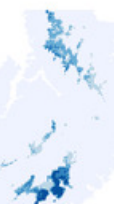

(f) 2050 RCP 6.0

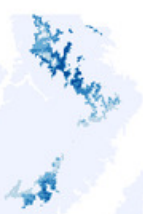

(b) 2050 RCP 2.6

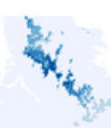

4
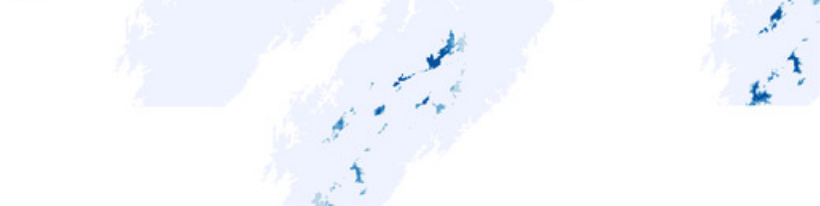

(e) 2070 RCP 4.5
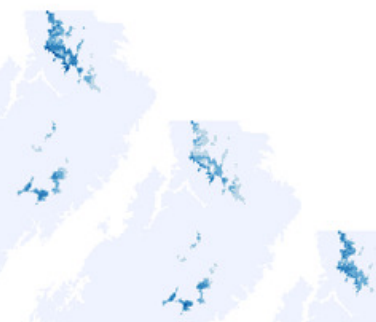

(g) 2070 RCP 6.0
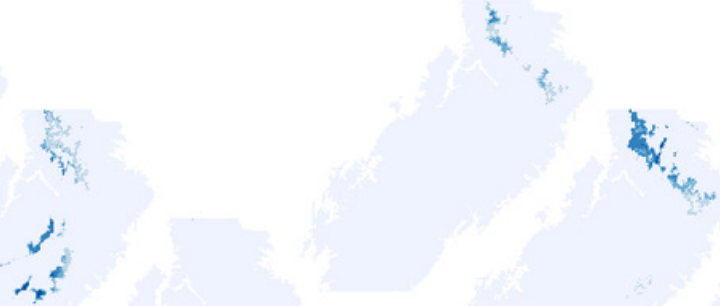

(h) 2050 RCP 8.5

(i) 2070 RCP 8.5 


\section{Figure 5}

Trajectories of bioclimatic change within the study area.

A principal component analysis (PCA) was applied to present-day bioclimatic variables to create three-dimensional climate space. The core areas $(p=0.75)$ of current and future climate are shown as ellipses. The current climate conditions are visualised by the black ellipse, with the 10 coloured ellipses visualising the core area of future climate conditions for each general circulation model (GCM) at 2070 under relative concentration pathway 8.5, which represents the most extreme future scenario. For an animated version of this figure please see Supplementary Figure S3. 


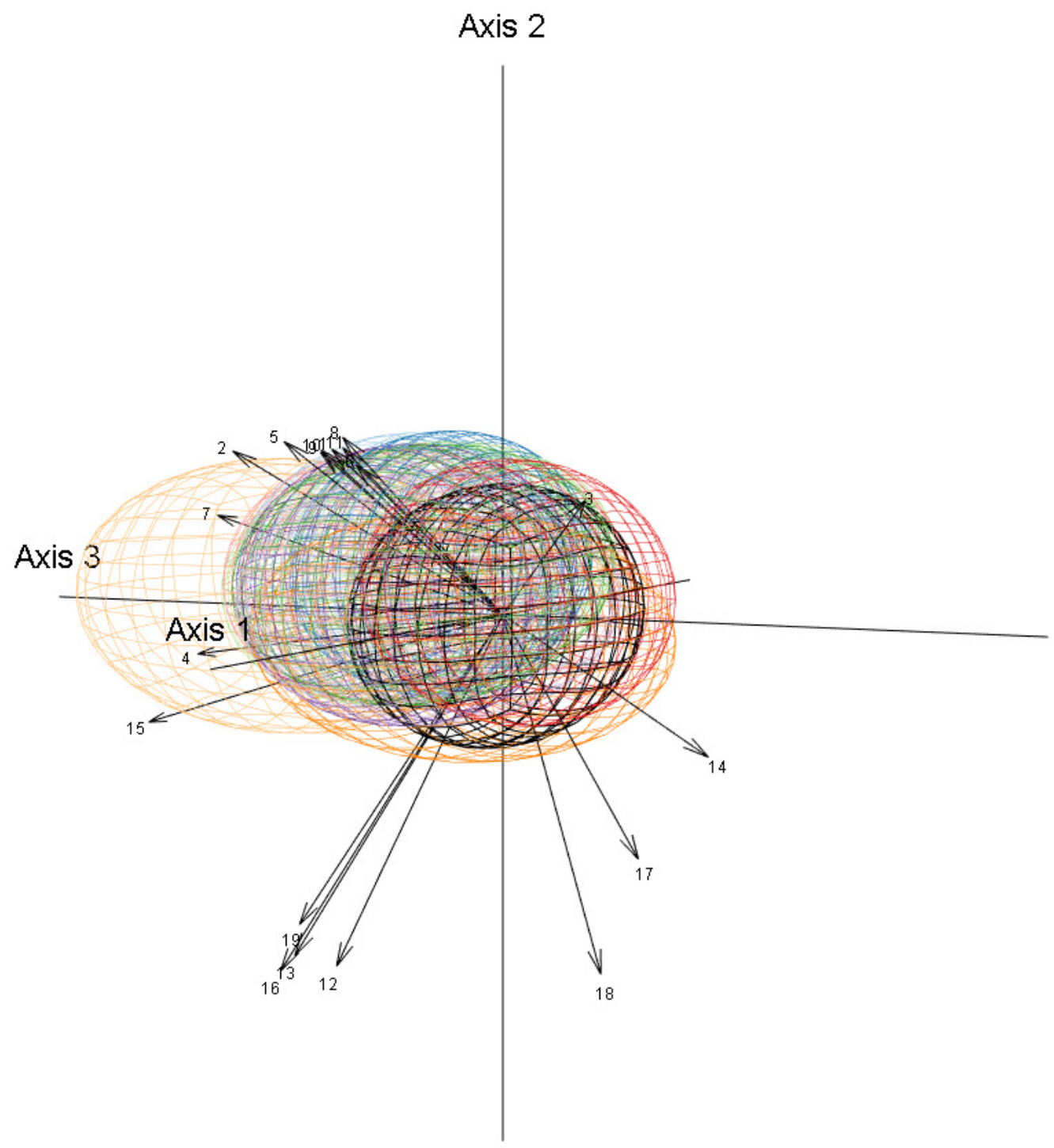




\section{Figure 6}

Beanplots of potential niche area change for level two ecosystem services under climate change.

Each bean represents the combined distribution of potential niche area change generated by 1,000 bootstrap resamples of a number ( $n$ ) species associated with an ecosystem service. Beans are presented for the predicted climates at 2050 and 2070 under the four different RCP scenarios. Ecosystem services include: (a) cultural - leisure, $n=1$; (b) cultural - magic or religious, $n=3$; (c) cultural - social, $n=2$; (d) provision - food for animals, $n=21$; (e) provision - gene sources, $n=1$; (f) provision - food for humans, $n=13$; (g) provision material, $n=37$; (h) provision - medicinal, $n=84$; (i) regulating - agroforestry, $n=1$; (j) regulating - biological control, $n=4$; $(\mathrm{k})$ regulating - erosion regulation, $n=12$; (I) regulating - pollination, $n=17 ;(\mathrm{m})$ regulating - restoration, $n=28 ;(n)$ regulating - water regulation, $n$ $=15$; (o) supporting - aesthetic values, $n=24$; $(p)$ supporting - barriers/windbreaks/support, $n=25$; (q) supporting - conservation, $n=3$; (r) supporting - nutrient cycling, $n=3$; (s) supporting - soil formation, $n=5$. 


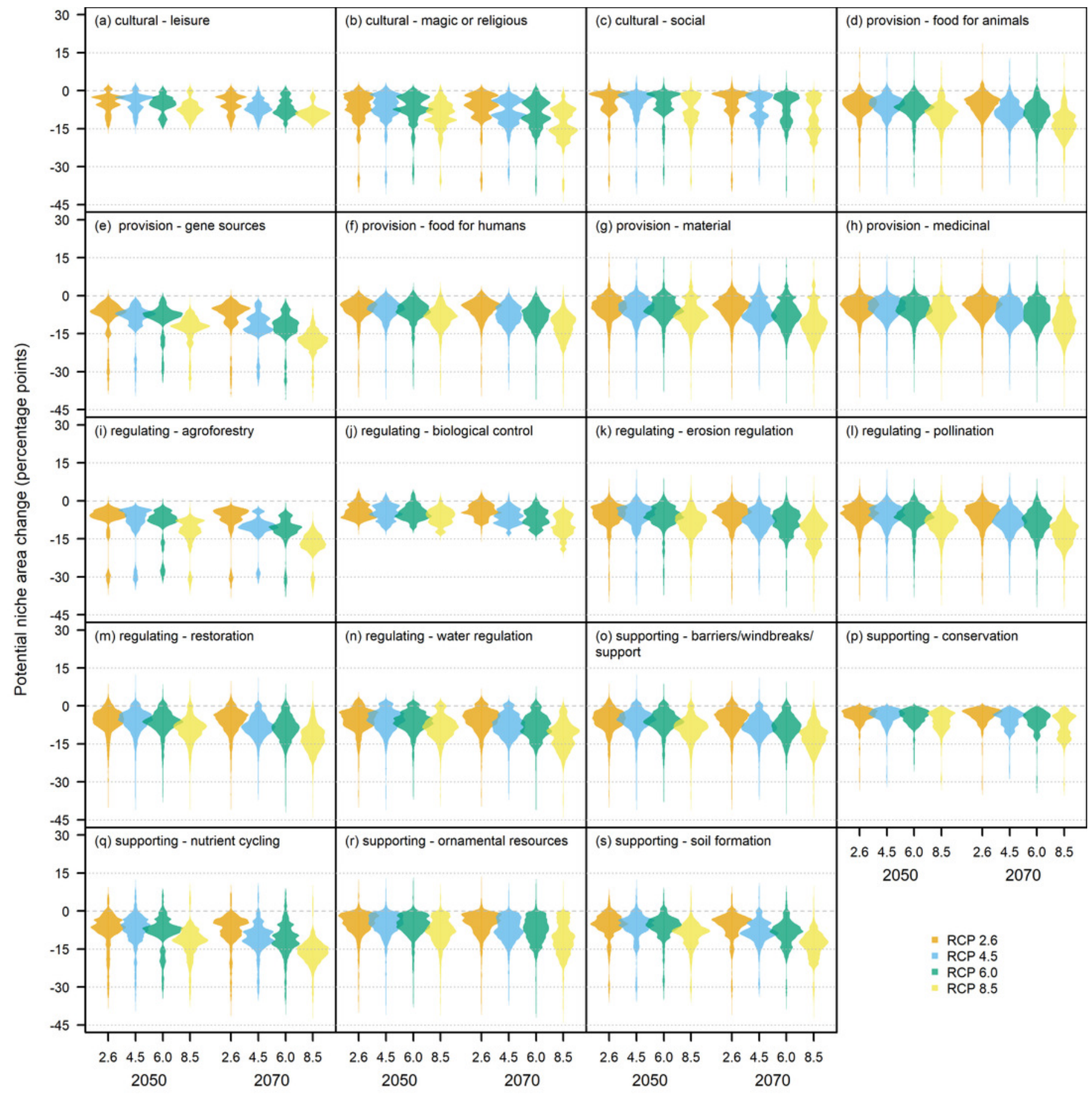




\section{Figure 7}

Beanplots of potential niche area change for level one ecosystem services under climate change.

Each bean represents the combined distribution of potential niche area change generated by 1,000 bootstrap resamples of a number ( $n$ ) species associated with an ecosystem service. Beans are presented for the predicted climates at 2050 and 2070 under the four different RCP scenarios. Ecosystem services include: (a) cultural, $n=6$; (b) provision, $n=157$; (c) regulating, $n=77 ;(d)$ supporting, $n=60$. 


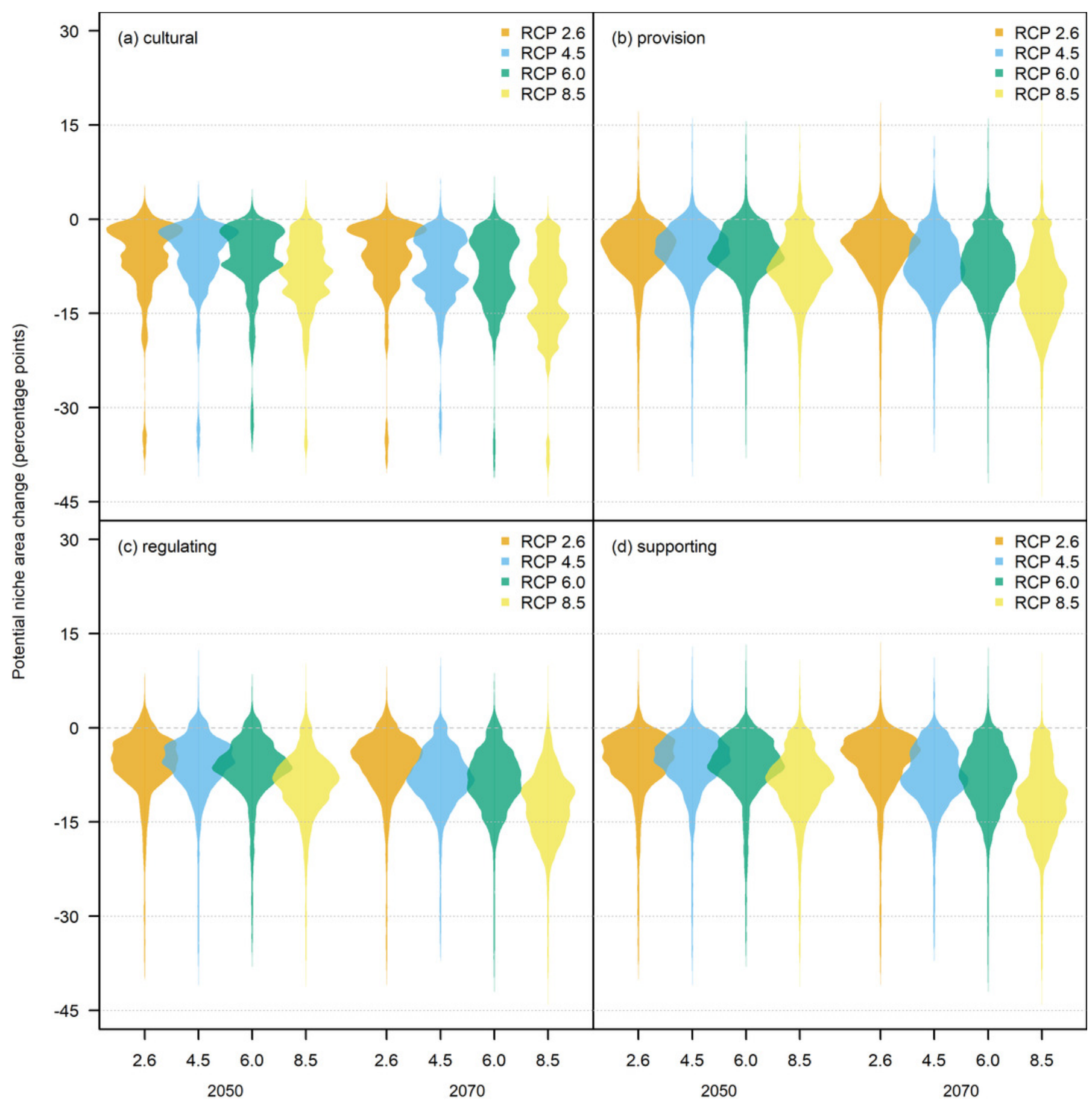

